2. Historia del Derecho canónico 

Revista de Estudios Histórico-Jurídicos

[Sección Historia del Derecho Canónico]

XXXV (Valparaíso, Chile, 2013)

[pp. 215 - 254]

\title{
Los concordatos celebrados entre la Santa Sede Y LOS PAÍSES LATINOAMERICANOS DURANTE EL SIGLO XIX
}

\author{
[The Concordats held between the Holy See and Latin American Countries in \\ the 19th Century]
}

\author{
Carlos Salinas Araneda* \\ Pontificia Universidad Católica de Valparaíso, Chile**
}

\begin{abstract}
RESUMEN
A partir de 1848 , año que marca el fin de la Restauración, hasta fines del siglo XIX la Santa Sede desplegó una actividad diplomática que la llevó a la firma de una docena de concordatos con los países latinoamericanos, bajos los pontificados de Pío IX y León XIII, cuyos contenidos son estudiados, al tiempo que se les sitúa en el contexto histórico en que surgieron y la suerte final de todos ellos.

Palabras clave

Concordatos-Concordatos latinoamericanos - Concordatos de Pío IX - Concordatos de León XIII.
\end{abstract}

\section{Abstract}

As from 1848, which was the end of Restoration, until the late $19^{\text {th }}$ century, the Holy See deployed a diplomatic activity that led to the signature of dozens of concordats with Latin American countries, under the pontificates of Pius IX and Leo XIII, contents of which are studied herein, as well as placing them within the historical context in which they were originated and their final destination.

$$
\begin{aligned}
& \text { KeYwORDS } \\
& \text { Concordats - Concordats - Latin } \\
& \text { American - Concordats of Pius IX - Con- } \\
& \text { cordats of Leo XIII. }
\end{aligned}
$$

RECIBIDO el 22 de mayo y ACEPTADO el 14 de junio de 2013

* Catedrático de Historia del Derecho y Derecho Canónico en la Pontificia Universidad Católica de Valparaíso. Dirección postal: Pontificia Universidad Católica de Valparaíso, Facultad de Derecho, Avenida Brasil 2950, Valparaíso, Chile. Correo electrónico: csalinas@ucv.cl

** Esta investigación ha sido realizada con ocasión del Proyecto Fondecyt 1120345 del que su autor es investigador responsable. 


\section{INTRODUCCIÓN}

Los primeros concordatos celebrados por la Santa Sede y los países latinoamericanos, que se habían sumado a los países independientes durante la primera mitad del siglo XIX, fueron celebrados por el papa Pío IX (1846-1878) en el decenio que va de 1851 a 1862, el primero de los cuales fue el celebrado con Bolivia en 1851. Le siguieron los de Costa Rica (1852), Guatemala I (1851), Haití (1860), Ecuador I (1861) Honduras (1861), Nicaragua (1861), Salvador (1862) y Venezuela (1962), a los que hay que agregar los firmados bajo el pontificado de su sucesor, León XIII (1878-1903): Ecuador II (1881), Guatemala II (1884) y Colombia (1887 y 1891). En otras palabras, dichos acuerdos internacionales se celebraron con cuatro naciones de América del Sur y seis de América Central.

Para situar estos concordatos en su correcta interpretación, preciso es tener presente, por una parte, que todos los países americanos, después de su independencia política respecto de la corona española, había reivindicado para sí el derecho de patronato, sintiéndose continuadores del mismo, lo que va a constituir el tema de mayores fricciones en las relaciones entre la Iglesia y las nuevas repúblicas. Por otra parte, la realidad política de estas nuevas naciones no fue pacífica a lo largo del siglo, sucediéndose gobiernos conservadores y liberales contrarios a la Iglesia, todo lo cual tuvo una incidencia en la vigencia de dichos concordatos, alguno de los cuales, paradójicamente el primero de ellos, el concordato con Bolivia de 1851, ni siquiera alcanzó a ser ratificado por el gobierno. Hacia mediados de siglo, fecha en la que se suscribe la mayoría de estos acuerdos, se asiste a un regreso general de gobiernos conservadores los que, hacia la década de los años 70 , serán sustituidos por regímenes de corte liberal no siempre adictos a la Iglesia ${ }^{1}$.

La actividad concordataria con naciones hispanoamericanas a partir de 1848, año que marca el fin de la restauración y el avance del Estado liberar hostil a la Iglesia, no fue menor en el conjunto de la actividad diplomática desplegada por la Santa Sede en ese período, pues, aparte de algunas convenciones menores, una quincena de concordatos fueron concluidos en los primeros años del pontificado de Pío IX (1846-1878), de los cuales seis fueron con países europeos ${ }^{2}$ y nueve con países latinoamericanos; y de los cinco celebrados bajo León XIII (1878-1903), tres fueron celebrados con países americanos y solo dos con países europeos ${ }^{3}$.

\footnotetext{
${ }^{1}$ Minnerath, Roland, L'Église et les États concordataires (1846-1981). La souveraineté spirituelle (Paris, Les Éditios du Cerf, 1983), pp. 435-440; El MISMO, L'Église catholique face aux États. Deux siècles de pratique concordataire 1801-2010 (Paris, Les Éditions du Cerf, 2012), pp. 46-59.

${ }^{2}$ Rusia (1847), España (1851), Austria (1855), Indias portuguesas I (1857), Wurtemberg (1857), Baden (1859).

${ }^{3}$ Indias portuguesas II (1886), Montenegro (1886).
} 


\section{Concordato con la República de Bolivia DE 29 DE MAYO DE $1851^{4}$}

La importancia de este concordato, aun cuando no fue ratificado, estriba en que se trata del primero de los celebrados con países latinoamericanos y, por lo mismo, serviría de modelo a los que le siguieron en cuanto a su contenido, salvadas, claro está, las particularidades de cada una de las naciones signatarias.

Una vez proclamada le independencia en Chuquisaca, el 6 de agosto de 1825 , siguieron unas décadas de clara anarquía con la excepción, quizá, de Adolfo Ballivian (1841-1847), hombre de espíritu progresista que emprendió la colonización de grandes zonas orientales e hizo venir de Francia religiosas para la educación de los niños. En 1847, sin embargo, cuando había conseguido mucho en diversas esferas de la actividad pública, fue derribado por un levantamiento militar que llevó al poder al general Guillart que, a su vez, debió cederlo al general Manuel Isidro Belzú, con quien se abrió la era de los autócratas militares a partir de diciembre de 1848. A pesar de la violencia con que ejerció el mando, sería el primer presidente que no terminaría su gobierno derrocado por una revolución, lo que ocurrió en 1855 . Fue, pues, durante su mandato que se firmó el concordato, pero fue también durante su gobierno, y en los siguientes, que dicho concordato no recibió la ratificación de Bolivias.

\section{Confesionalidad del Estado.}

El concordato se abre con una solemne declaración de confesionalidad del Estado de manera que: "La Religión Católica, Apostólica, Romana continuará siendo la Religión de la República de Bolivia, y se conservará siempre con todos los derechos y prerrogativas de que debe gozar, según la ley de Dios y las disposiciones de los Sagrados Cánones" (artículo 1). Dicha confesionalidad traía consecuencias para la Iglesia, las que se reglaban en los artículos siguientes. La primera decía relación con la enseñanza la cual en las universidades, colegios, escuelas públicas y privadas y demás establecimientos de instrucción debía ser "conforme a la doctrina de la misma Religión Católica”. Para que ello fuera a así, los obispos y demás ordinarios locales tendrían la libre dirección de las cátedras de teología, de Derecho canónico, de todos los ramos de enseñanza eclesiástica "a más de la influencia que ejercerán en fuerza de su ministerio, sobre la educación religiosa de la juventud, velarán porque en la enseñanza de cualquier otro ramo no haya nada contrario a la Religión y a la moral" (artículo 2). Además, los obispos conservaban su "derecho de censura sobre todos los libros y escritos que tengan relación al dogma, a la disciplina de la Iglesia y a la moral pública", comprometiéndose el gobierno a concurrir con los propios de su autoridad a sostener las disposiciones que tomaren los prelados "conforme

\footnotetext{
${ }^{4}$ Su texto en Enchiridion dei concordati. Due secoli di Storia dei rapporti Chiesa-Stato (Bologna, Dehoniane, 2003), pp. 174-193, No 364-394.

${ }^{5}$ Arjona Colomo, Miguel, Historia de América, II: América del Sur (Madrid, Epesa, 1976), p. 72; Gran Enciclopedia Rialp Ger (Madrid, Ediciones Rialp, S.A., 1991), IV, s.v. Bolivia independiente: la Iglesia y el Estado, p. 374; SÁNCHEZ, Luis Alberto, Historia General de América (4a ed., Santiago, Ediciones Ercilla, 1945), II, pp. 321-323.
} 
a los Sagrados Cánones para tutelar la Religión, y evitar todo lo que pudiera serle contrario" (artículo 3).

Otra consecuencia favorable a la Iglesia como consecuencia de la confesionalidad, era la libre comunicación que tendrían los obispos, el clero y el pueblo con la Santa Sede, "siendo el Pontifice el Jefe de la Iglesia Universal por derecho Divino" (artículo 4). Se trataba de un tema de especial relevancia para la Iglesia toda vez que durante el período hispano, la monarquía española se había encargado celosamente de impedir la relación directa de las iglesias locales del Continente con la Santa Sede.

Pero la confesionalidad traía obligaciones para el Estado, por lo que el gobierno boliviano se comprometía " a conservar la dotación de los obispos, cabildos y seminarios, y a proveer a los gastos del culto y de fábrica de la Iglesia, de los fondos del Tesoro nacional' conforme a la escala específica que se encontraba al final del concordato. La misma norma se encargaba de aclarar que dichas asignaciones eran "un compensativo de los diezmos menoscabados en gran parte por los trastornos pasados" por lo que debían entenderse como a título oneroso y eran reconocidas por el gobierno como verdadero crédito de las Iglesias contra la nación de Bolivia, adquiriendo el "carácter de una verdadera renta independiente"(artículo 5). Por su parte, los párrocos seguirían percibiendo las primicias y los emolumentos dichos de estola, cuyos aranceles serían arreglados por los ordinarios concienzudamente, "hasta que pudiere el Gobierno asignarles una congrua segura e independiente, poniéndose para ello de acuerdo con los Obispos" (artículo 6).

\section{Patronato.}

En vista de los compromisos que asumía el gobierno boliviano, el papa concedía al presidente de la República y a sus sucesores en este cargo "el patronato o sea el privilegio de presentar para cualesquiera vacantes de Iglesias Arzobispales u Obispales, a Eclesiásticos dignos e idóneos, adornados de todas las cualidades requeridas por los Sagrados Cánones; y el Sumo Pontifice en conformidad a las reglas prescritas por la Iglesia, dará a los presentados la institución canónica en las formas acostumbradas". El derecho de p r e s e n t a c i ó n era el más importante de los derechos que el patronato otorgaba a las autoridades civiles; pero, con el correr del tiempo, durante la monarquía indiana se había desarrollado la corruptela del llamado g obierno de los presentados, es decir, la petición que hacían las autoridades reales para que el presentado empezara el gobierno de la iglesia local para la que había sido presentado antes de que fuera nombrado por el papa. Esta corruptela había sido continuada por los gobiernos republicanos, razón por la cual, en este concordato, inmediatamente después de conceder el derecho de presentación, se establecía que "no podrán los presentados intervenir de ningún modo en el régimen o administración de las Iglesias, para las cuales hubiesen sido designados, antes de recibir las Bulas de institución Canónica, como está prescrito en los Sagrados Cánones”. Producida la vacante, el presidente de la república tenía el término de ocho meses para hacer la presentación, término que se contaba desde el día de la vacante (artículo 7).

Por el mismo derecho de patronato, el papa concedía al presidente de la re- 
pública "el indulto de nombrar en cada Capitulo para seis prebendas" ya fueren de dignidades o racioneros, exceptuando la primera Dignidad, "que será reservada a la libre colación de la Santa Sede, y la Doctoral, Penitenciaria y Magistral, las cuales serán conferidas por los Obispos, en concurso de oposición, a las personas que fuesen consideradas más dignas" (artículo 8).

El derecho de patronato se extendía también a los párrocos, de manera que todas las parroquias serían provistas mediante concurso abierto, tal como lo disponía el Concilio de Trento", debiendo los ordinarios "formar las ternas de los concurrentes aprobados y dirigirla al presidente de la República, quien nombrará uno entre los propuestos, conforma a la práctica observada hasta ahora" (artículo 9).

Junto al derecho de patronato iba unido el juramento que debían prestar los eclesiásticos designados en los diversos oficios, juramento que, si bien era considerado también un abuso, se conservaba en este concordato, pero con una aclaración, pues se dejaba en claro "la declaración del Gobierno emitida por medio de su Plenipotenciario, en cuanto al juramento, de que no es su mente obligar en conciencia a quien lo presta a cosa contraria a la ley de Dios y de la Iglesia". A la luz de ella y en vista de la misma, el papa consentía en que los obispos y demás eclesiásticos prestaran juramento según la fórmula que consignaba el mismo concordato: "Yo juro y prometo a Dios sobre los Santos Evangelios obedecer y ser fiel al Gobierno establecido por la Constitución de la República de Bolivia y prometo asimismo no ingerirme personalmente ni por medio de Consejos, en proyecto alguno que pueda ser contrario a la Independencia Nacional o a la tranquilidad pública" (artículo 23).

\section{Erección de nuevas diócesis, nuevas parroquias y seminarios.}

En ejercicio de su propio derecho la Santa Sede podría erigir nuevas diócesis y hacer nuevas circunscripciones de las existentes, según lo requirieren las necesidad y la utilidad de los fieles. Para ello, sin embargo, llegado el caso, "procederá de inteligencia con el Gobierno Boliviano". En cada una de estas diócesis se establecería un cabildo de canónigos y un colegio seminario proporcionado al número del clero diocesano y a las necesidades de la nueva diócesis; y para la dotación, tanto de las sillas que habrían de erigirse en los cabildos, como para los seminarios, se procedería sobre las bases establecidas para los otros ya existentes, "poniéndose la Santa Sede de acuerdo con el Gobierno, para que dichas dotaciones sean decorosas e independientes" (artículo 10).

Por su parte, los Ordinarios respectivos podrían erigir nuevas parroquias según lo requirieren las necesidades y la utilidad de los fieles, pero en cada caso debía procederse "de inteligencia con el Gobierno, siempre que fuere necesario conciliar los efectos civiles" (artículo 11).

En cuanto a los colegios seminarios, se conservarían los existentes y, en aquellas diócesis donde faltaren, se erigirían inmediatamente, correspondiendo su dotación al gobierno. Pero ninguna intervención le correspondía al gobierno, ni en la admisión de los alumnos, ni en el régimen del mismo ni de sus autoridades y

\footnotetext{
${ }^{6}$ Conc. Trid., sess. XXIV, de ref. cap. $18^{\circ}$.
} 
profesores, pues quedaba claro en el concordato que serían "recibidos y educados en ellos, conforme a lo prescrito por el Sacro Concilio de Trento ${ }^{7}$, aquellos jóvenes, a quienes los Obispos creyeren conveniente admitir, según la necesidad y utilidad de sus diócesis. Corresponde por consiguiente el pleno y libre derecho a la autoridad de los Prelados Diocesanos todo cuanto concierne al arreglo, a la enseñanza, al régimen y a la administración de los Seminarios, cuyos Rectores y Profesores serán libremente nombrados y revocados por los Obispos, cuando juzgaren conveniente" (artículo 12).

\section{Sedes episcopales vacantes.}

El concordato se encargaba también de fijar lo que había que hacer cuando se producía la vacante de una sede arzobispal o episcopal: el cabildo de la iglesia metropolitana o sufragánea debía nombrar libremente en el término prefijado y en conformidad con lo establecido en el Concilio de Trento ${ }^{8}$, esto es, dentro de ocho días después de la muerte del obispo, al vicario capitular, "sin poder revocar el nombramiento una vez hecho, ni hacer otro nuevo, quedando por consiguiente abolida cualquiera costumbre que fuese contraria a lo dispuesto por los Sagrados Cánones" (artículo 14).

\section{Tribunales y procesos.}

Venían después diversos artículos que abordaban aspectos diferentes referidos a las actuaciones procesales. Por de pronto, las causas concernientes a la fé, a los sacramentos, a las funciones sagradas, a las obligaciones y a los derechos anejos al sacramente del Orden, que en el concordato era denominado "Sagrado Ministerio", $\mathrm{y}$, en general, todas las causas de naturaleza eclesiástica pertenecían "exclusivamente al juicio de la autoridad Eclesiástica, según las reglas de los Sagrados Cánones" (artículo 14). En cambio, "atendiendo a las circunstancias de los tiempos", el papa consentía en que se definieran por los tribunales laicos, las causas personales de los eclesiásticos en materia civil, así como las causas reales que concernieren a las propiedades y a otros derechos temporales, tanto de los clérigos como de las iglesias, de los beneficios y de las demás fundaciones eclesiásticas (artículo 15).

Por la misma razón, es decir, por "las circunstancias de los tiempos", la Santa Sede no hacía dificultad a que las causas criminales de los eclesiásticos por delitos perseguidos por las leyes de la república, extrañas a la religión, fueren deferidas a los tribunales laicos. Pero en estas causas, en la segunda y en la última instancia entrarían a hacer parte del tribunal, en calidad de conjueces, al menos dos eclesiásticos nombrados por el ordinario. Estos juicios no serían públicos y las sentencias que resultaren de ellos, en caso de condenación a pena capital, aflictiva o infamante, no se ejecutarían sin la aprobación del presidente de la república, y sin que el respectivo ordinario hubiere cumplido previamente cuanto en tales casos fuere requerido por los sagrados cánones. En todo caso, "en la disposición contenida en este artículo, siempre se entienden excluidas las causas mayores, las que son reservadas a la Santa Sede, conforma a lo dispuesto por el Concilio de Trento"

${ }^{7}$ Conc. Trid., sess. XXIII, de ref. cap. $18^{\circ}$.

${ }^{8}$ Conc. Trid., sess. XXIV, de ref. cap. $16^{\circ}$.

${ }^{9}$ Se trata de las causas criminales de más gravedad contra los obispos y también las de he- 
(artículo 16). En el arresto y detención de los eclesiásticos debían usare "los miramientos convenientes a su carácter, debiendo darse pronto aviso de dicho arresto al Obispo respectivo" (artículo 16).

En lo referido a las faltas de los eclesiásticos a los deberes de su oficio y por las de su conducta moral, los ordinarios podían corregirlos conforme a la disciplina vigente, en atención a que eran "enteramente libres en el ejercicio de su ministerio" (artículo 17).

\section{Régimen de bienes de la Iglesia.}

Se reconocía en forma expresa el derecho que tiene la Iglesia "de adquirir por cualquier título justo", de manera que "sus adquisiciones y las fundaciones piadosas serán respetadas y garantidas a la par de las propiedades de todos los ciudadanos bolivianos". Y en cuanto a las fundaciones, no podrían ser suprimidas ni unidas "sin la intervención de la autoridad de la Santa Sede", salvas las facultades que competían a los obispos según lo dispuesto en el Concilio tridentino (artículo 18) ${ }^{10}$.

Por los mismos años en que se celebraba este concordato, Justo Donoso ${ }^{11}$, autor del más extendido manual de derecho canónico de la América hispana del siglo XIX, enseñaba que "la inmunidad real consiste... en que los bienes de las iglesias y personas eclesiásticas sean inmunes, libre y exentos de toda carga, contribución y exacción impuesta por la autoridad seglar", no obstante lo cual agregaba que "en el estado actual de las sociedades, en Europa y en América, gravísimas heridas ha recibido la inmunidad real de las iglesias y personas eclesiásticas, pudiéndose decir, en general, que apenas quedan vestigios de ella”. En esta misma línea, el concordato disponía que la Santa Sede, "en vista de las circunstancias actuales, consciente en que los fondos o bienes Eclesiásticos sean sometidos a las cargas públicas, a la par de los bienes de los Ciudadanos Bolivianos excepto siempre las fábricas destinadas al culto Divino, es decir, las Iglesias" (artículo 19).

Y también había un artículo que regulaba expresamente la condición jurídica de los bienes que en los años anteriores habían sido usurpados a la Iglesia y que ahora se encontraban manos de particulares. En efecto, según el artículo 20: “atendida la utilidad que resulta para la Religión del presente concordato, el Santo Padre a instancias del presidente de la República de Bolivia, por proveer a la tranquilidad pública: decreta y declara, que las personas, que durante las vicisitudes pasadas hubiesen comprado bienes Eclesiásticos, o redimido censos en los dominios de ella, autorizados por las leyes civiles vigentes en aquellos tiempos, tanto los que se hallen en posesión cuanto los que hayan sucedido o sucedieren de derecho a los dichos compradores, no serán molestados en ningún tiempo y de ninguna manera por Su Santidad, ni por los Sumos Pontifices sus sucesores; de modo que los primeros compradores, lo mismo que sus legitimos sucesores, gozan segura y pacificamente de las propiedad de dichos bienes,

rejía, que merezcan deposición o privación. Cf. Conc. Trid., sess. XXIV de ref. cap. $5^{\circ}$. Véase también Conc. Trid., sess. XIII de ref. cap $8^{\circ}$.

${ }^{10}$ Conc. Trid., sess. XXI de ref. cap. $5^{\circ}$

${ }^{11}$ Donoso, Justo, Instituciones de Derecho canónico americano (Valparaíso, Imprenta y librería del Mercurio, 1849), II, pp. 270, 272. 
de sus respectivos emolumentos y productos, siendo entendido, que no se renovarán esas enajenaciones abusivas".

\section{Monasterios, regulares y misiones.}

Disponía el concordato que los monasterios, tanto de mujeres como de varones, existentes al momento del concordato, se conservarían en el territorio de la República de Bolivia y no se impediría el establecimiento de otros. A su vez, "las cosas relativas a regulares" serían arregladas según lo establecido por las leyes canónicas y las respectivas constituciones de las órdenes religiosas (artículo 21). Se reconocía en esta materia una amplia libertad de actuación a la Iglesia. Por su parte, el gobierno se obligaba a suministrar los medios adecuados "para la propagación de la Fe y para la conversión de los infieles existentes dentro de los limites de su territorio" al tiempo que favorecería el establecimiento y progreso de las misiones "que con tal laudable objeto llegasen al territorio de la República, autorizadas por la Sagrada Congregación de Propaganda Fide” (artículo 22).

\section{Oraciones por la república y su presidente y privilegios castrenses.}

No es para la Iglesia ninguna novedad orar por las autoridades, siendo la del papa Clemente Romano (91-101) la más antigua de las oraciones que se conocen por la autoridad política ${ }^{12}$. Durante el período indiano se rezaba por el rey de España ${ }^{13}$ y el concordato vuelve sobre ello al disponer que "después de los Oficios Divinos en todas las Iglesias de Bolivia, se hará la siguiente oración: 'Domine salvam fac Rempublicam. Domine salvum fac Praesidem eius'” (artículo 24).

En lo que al ejército se refería, el papa concedía a los ejércitos de la república de Bolivia "todas las exenciones conocidas bajo la denominación de privilegios castrenses", para, después, determinar en un breve contemporáneo a la publicación del concordato, cada una de las gracias y exenciones que se entendía conceder (artículo 25).

\section{Artículos finales.}

La primera de las cuatros disposiciones finales del concordato, en forma general establecía que todo lo que no quedaba arreglado expresamente por los artículos del concordato, ya perteneciere a cosas ya a personas eclesiásticas, sería dirigido y administrado conforme a la disciplina vigente de la Iglesia católica (artículo 26), al tiempo que quedaban abrogadas por el concordato todas las leyes, ordenanzas y decretos promulgados de cualquier modo y en cualquier tiempo en la república de Bolivia, entendiéndose el concordato como ley del Estado "que debe tener fuerza y valor en adelante” (artículo 27). En lo que se refiere a la ratificación, el concordato sería ratificado legalmente por ambas partes y la ratificaciones canjeadas en Roma, dentro del término de 18 meses "o antes si fuese posible" (artículo 28). Luego que fuesen canjeadas las ratificaciones del concordato, el papa lo confirmaría con sus letras apostólicas (artículo 29).

\footnotetext{
${ }^{12}$ Catecismo de la Iglesia Católica, No 1900.

${ }^{13}$ P. ej. Rec. Ind. 1,2,12.
} 


\section{Valoración general.}

Una valoración general del concordato muestra un equilibrio entre los derechos de la Iglesia y del Estado boliviano. Si bien hay un reconocimiento expreso del patronato,ero entendido como una concesión de la Santa Sede y no como un derecho del Estado, con las consecuencias que derivaban de un tal estado de cosas, también había un reconocimiento expreso de la libertad de la Iglesia en ámbitos no menores como lo que se refería a lo que hoy se denomina la vida consagrada en sus diversas manifestaciones, al tiempo que había también un amplio reconocimiento del derecho canónico en diversos momentos. En otras palabras, el concordato venía a reconocer una situación de hecho y a poner fin a heridas que, de seguir, habrían complicado más las relaciones entre ambos poderes, como el saneamiento de lo referido a las expoliaciones de bienes de que había sido objeto la iglesia boliviana.

Este concordato, sin embargo, nunca entró en vigencia porque no fue ratificado por el gobierno boliviano, a pesar de la conveniencia que suponía para él la firma de este acuerdo. La razón, o excusa, que se brindó fue que el patronato era entendido en el concordato como una concesión graciosa que hacía la Iglesia y no como un derecho inherente a la república. Pero fue el modelo que se tuvo a la vista para la redacción de los demás concordatos que se firmaron en los años inmediatamente siguientes con países latinoamericanos.

\section{Concordato entre Pío IX y el presidente de la República de Costa Rica DE 7 DE OCTUBRe DE $1852^{14}$}

Costa Rica obtuvo la independencia de la gobernación de Guatemala en octubre de 1821, pero, después de algunos intentos federativos en centro América, obtuvo su independencia absoluta el 30 de agosto de 1848, debiendo derrotar en los años inmediatamente siguientes al filibustero William Walker, definitivamente derrotado en 1856. El 28 de febrero de 1850 se creó la diócesis de San José de Costa Rica y, al año siguiente, se firmó el concordato, al amparo del cual entraron algunos religiosos, como la congregación de la Misión, lazaristas, y también los jesuitas.

El concordato con Costa Rica tomó como modelo el concordato celebrado el año anterior con Bolivia al que siguió de cerca no sólo en el contenido, sino que también en el orden en que fueron reguladas las materias. Se iniciaba con la declaración de confesionalidad, al igual que su modelo, si bien en vez de afirmar que la religión católica "continuará siendo la Religión de la República" utiliza la fórmula de que la "Religión Católica Apostólica Romana es la Religión del Estado en la República de Costa Rica” (artículo 1). De esta declaración se deducían las mismas consecuencias definidas en el modelo boliviano, referidas a la enseñanza (artículo 2) y al derecho de censura de los obispos (artículo 3), en los mismos términos que el concordato boliviano, cuyas disposiciones eran copiadas con leves retoques de

\footnotetext{
${ }^{14}$ Su texto en Enchirdion, cit. (n. 4), pp. 192-209, № 395-424; también en MERCATI, Angelo (a cura di), Raccolta di concordati su materie ecclesiastiche tra la Santa Sede e le autorità civili, I: 1098-1914 (Tipografia Poligotta Vaticana, 1954), pp. 800-809.
} 
redacción. De la misma manera se reconocía el derecho de comunicarse libremente con la Sede Apostólica (artículo 4) y el gobierno de Costa Rica se comprometía a suministrar las dotaciones económicas necesarias, en términos idénticos al modelo boliviano cuyo artículo 5 transcribía casi textualmente, con la diferencia que en el modelo se afirmaba que el gobierno de comprometía a "continuar" con dichas dotaciones, a diferencia del concordato costarricense en que el compromiso era para "suministrar" las mismas; y en el concordato centroamericano se agregaba la dotación de los nuevos obispados. De la misma manera, los párrocos seguirían recibiendo las primicias y derechos de estola hasta que el gobierno pudiere asignarles "una congrua segura e independiente" (artículo 6). Consecuencia de todo ello, particularmente de la dotaciones a que se comprometía el gobierno, "mayores en su totalidad de lo que produce actualmente la renta de diezmos y que el Gobierno espera aumentar en el tiempo venidero", era la concesión al presidente de la república y a sus sucesores del patronato, "o sea el privilegio de presentar para cualesquiera vacantes de la Diócesis de San José y de las demás que fueren erigidas en aquel territorio"; se prohibía el abuso del gobierno de los presentados y se ampliaba a un año el plazo para la presentación del candidato después del día en que se había verificado la vacante (artículo 7).

Por la misma razón, igual que el modelo boliviano, se otorgaba al presidente de la república el privilegio de nombramientos en los cabildos eclesiásticos, con la diferencia formal de redactar en dos incisos separados lo que en el concordato boliviano se redactaba en uno solo (artículo 8). Se seguía a la letra lo referido al nombramiento de los párrocos, con la diferencia de que en el concordato centroamericano se hacía referencia "a la práctica observada en otras Repúblicas de la América antiguamente española" (artículo 9), en vez de la genérica referencia "a la práctica observada hasta ahora" del concordato con Bolivia". Se reconocía que "la Santa Sede en ejercicio de su propio derecho, erigirá nuevas diócesis" para lo cual deberá proceder "de acuerdo" con el gobierno, fórmula más estricta que la utilizada con Bolivia en donde las nuevas erecciones se harían "en inteligencia" con el gobierno (artículo 10). El régimen de los seminarios, regulado en el concordato boliviano en el artículo 12, se incorporaba en el concordato costarricense como inciso $2^{\circ}$ del artículo 10, por lo que a partir del artículo 12 la numeración del segundo de estos acuerdos no coincidía con el primero como había sucedido hasta dicho artículo. El artículo 12 del concordato que estoy describiendo, referido a la sede vacante y nombramiento del vicario capitular, copia textualmente el artículo 12 del concordato boliviano, y lo mismo sucede, con leves cambios de redacción, con lo referido a las causas concernientes a la fe (artículo 13), las causas personales de los clérigos en materas civiles (artículo 14), las causas criminales de los eclesiásticos por delitos perseguidos por las leyes de la república (artículo 15) y el derecho de corrección de los Ordinarios respecto de los eclesiásticos (artículo 16).

En materia patrimonial, el régimen seguido en el concordato con Costa Rica copiaba el establecido con Bolivia en lo referido a reconocer el derecho de la Iglesia

${ }^{15}$ La descripción de las prácticas para el nombramiento de los párrocos en la América antiguamente española se puede ver en: Donoso, Justo, cit. (n. 11), I, pp. 243-245. 
para adquirir por cualquier título justo (artículo 17), la aceptación por parte de la Iglesia de que sus bienes fuesen sometidos a las cargas públicas al igual que los de los ciudadanos (artículo 18) y el saneamiento de las propiedades eclesiásticas usurpadas en los años anteriores y actualmente en poder de civiles (artículo 19). Lo mismo sucedía con el establecimiento de monasterios o conventos de ambos sexos (artículo 20) y con la ayuda a la propagación de la fe y favorecimiento de las misiones (artículo 21). La fórmula del juramento que debían prestar los eclesiásticos era la misma que en Bolivia (artículo 22) y lo mismo la de las oraciones que debían rezarse después de los oficios divinos por la república y por el presidente (artículo 23); se copiaba igualmente el concordato boliviano en lo referido a las gracias y exenciones castrenses (artículo 24) y las cláusulas finales del mismo, en cuanto a todo lo que no se haya "arreglado expresamente" en los artículos anteriores (artículo 25), abrogación de las normas contrarias al mismo (artículo 26), ratificación en el término de 18 meses o antes, de ser posible (artículo 27) y confirmación del mismo por letras apostólicas (artículo 28).

Hacia la década de los años 80, empezaron a adoptarse medidas anticatólicas, debido a la presión de los Estados vecinos y de las logias: hubo conflictos a propósito de la secularización de los cementerios, la expulsión de los jesuitas en 1884 y la prohibición para que se instalaran en el país nuevas congregaciones religiosas, a pesar de la libertad que al efecto concedía el concordato, el que finalmente fue declarado insubsistente el 28 de julio de $1884^{16}$.

\section{Concordatos entre Pío IX y León XIII y el presidente de la República} de Guatemala de 7 DE OCTUbRe DE $1852^{17}$ y de 2 dE JUlio de $1884^{18}$

RESPECTIVAMENTE

Declarada la independencia de Guatemala en 1847, pronto accedió al poder Rafael Carrera, quien gobernó el país hasta 1865, año de su muerte, con elementos conservadores y clericales, durante un largo período caracterizado por la paz interna. Es en esos años en los que se firmó el concordato con la Santa Sede el que entró en vigencia en los términos fijados en el mismo ${ }^{19}$.

\section{Concordato de 7 de octubre de 1852.}

Fue firmado el mismo día que el concordato celebrado entre la Santa Sede y Costa Rica, interviniendo en ambos los mismos plenipotenciarios: por la Santa Sede, el cardenal Jacobo Antonelli, secretario de Estado, y por la República de

${ }^{16}$ Arjona Colomo, Miguel, cit. (n. 5), II, pp. 150-151; Minnerath, Roland, L'Église et les États, cit. (n. 1), p. 436; El MISMO, L'Église catholique, cit. (n. 1), p. 56.

${ }^{17} \mathrm{Su}$ texto en Enchiridion, cit. (n. 4), pp. 210-229, N 426-455; también en MerCati, Angelo, cit. (n. 14), I, pp. 810-821.

${ }^{18} \mathrm{Su}$ texto en Enchiridion, cit. (n. 4), pp. 458-463, N 844-861; también en Mercati, Angelo, cit. (n. 14), I, pp. 1018-1021.

${ }^{19}$ Arjona Colomo, Miguel, cit. (n. 5), II, p. 139; SÁnchez, Luis Alberto, cit. (n. 5), II, pp. 274-275. Lit.: Melgar GuZmán, Rafael Antonio, La Iglesia católica y el Estado en Guatemala, de la independencia a la revolución liberal (1821-1871), en Estudios Teológicos, 8 (Guatemala, 1981) 16, pp. 3-78. 
Guatemala, el marqués de Belmonte, don Fernando Lorenzana. La similitud entre ambos documentos es grande y, tal como sucede con el concordato costarricense, el concordato con Guatemala, además de haber entrado en vigencia, tiene como modelo inspirador el concordato con Bolivia del año anterior.

De hecho, el artículo 1, que declaraba la confesionalidad del Estado, era copia textual del concordato boliviano, y las dos inmediatas consecuencias referidas a la enseñanza (artículo 2) y a la censura que correspondía al obispo (artículo 3), si bien en éste el gobierno de Guatemala no sólo se comprometía a sostener con sus medios las disposiciones que tomaren los obispos, sino que hacía una expresa declaración de que "con sus leyes ha dado ya providencias sobre el particular". De la misma manera, quedaba asegurada la libre comunicación de los obispos, clero y fieles con Roma en los mismos términos que el modelo boliviano (artículo 4).

En materia patrimonial, se aseguraba la dotación económica a las iglesias, si bien con una modalidad diversa a la de los dos concordatos anteriores: en efecto, el gobierno guatemalteco se comprometía a conservar el pago del diezmo y obligar autoritativamente a él, siendo esta contribución sólo para la Iglesia sin ninguna reserva para el gobierno; pero, como el diezmo no ofrecía una renta suficiente al objeto a que estaba destinado, "el mismo gobierno suministrará de los fondos del tesoro nacional una asignación anual que mantendrá aun después de haberse mejorado los productos del Diezmo, y que se considera como un verdadero crédito de la Iglesia contra el Estado". Si por circunstancias "que no pueden ahora ser previstas" debiera hacerse alguna variación en los diezmos, ella no podría hacerse sino con la intervención "de la autoridad de la Santa Sede". Además, se establecía una Comisión de Eclesiásticos escogidos por el Ordinario, de ser posible entre los canónigos de la catedral, presidida por el mismo Ordinario o por el vicario capitular en sede vacante, cuya tarea sería cobrar y administrar las rentas que corresponderían al arzobispo o a los prebendados, en sede vacante, para "invertirlas según la necesidad y conforme al dictamen de la misma comisión en reparos de iglesias o en limosnas o en otros objetos cuya institución o naturaleza sea religiosa" (artículo 5).

Y lo mismo sucedía respecto de los párrocos, quienes, hasta que el gobierno no les asignare una congrua segura e independiente, seguirían percibiendo las primicias y los emolumentos llamados de estola, cuyos aranceles serían arreglados por el ordinario "concienzudamente", los cuales quedaban sujetos a ser revisados cuando conviniere, por el Ordinario "de acuerdo con el Gobierno por el apoyo que él prestará para el cobro de dichos emolumentos", con lo cual el gobierno, a diferencia de los que sucedía con los otros dos concordatos, se aseguraba una intervención en esta materia. Algo similar sucedía en lo referido a la inversión de unos fondos procedentes de derechos o impuestos llamados "de fábrica", en lo que el gobierno tendría la conveniente vigilancia "sin que por esto se entienda con derecho a la administración de estos ramos". Se trata de una originalidad de este concordato, que tampoco está presente en los demás. Otro añadido que no está en los otros dos concordatos era que, cuando el algunas parroquias faltaren los medios para el sostén de sus menesteres, el gobierno, "entendiéndose con el Ordinario" se comprometía a proveer lo que fuere necesario (artículo 6).

Consecuencia de los compromisos anteriores, al igual que su modelo, "el 
Sumo Pontifice concede al presidente de la República de Guatemala y a sus sucesores en este cargo, el Patronato", el que le daba el derecho de presentación de los obispos, quienes no podían entrar a gobernar hasta no recibir las bulas de institución canónica (artículo 7); el derecho de nombrar en cada capítulo seis prebendas (artículo 8); el derecho de intervenir en la provisión de las parroquias (artículo 9), en la creación de las nuevas circunscripciones erigidas por la Santa Sede (artículo 10) y de las nuevas parroquias (artículo 11), todo ello en los mismos términos que el concordato con Bolivia. En cambio, la Iglesia conservaba su libertad en lo referido a los seminarios (artículo 12) y a la elección de vicario capitular en sede vacante (artículo 13), al igual que su modelo. En materias procesales se recogían textualmente las disposiciones bolivianas en lo referida a las causas concernientes a la fe (artículo 14) y a las causas personales de los eclesiásticos en materias civiles; en éstas, sin embargo, se agregaba un dato nuevo: "si las demandas fueren entre todos eclesiásticos", correspondía a los obispos intervenir como árbitros con el fin de dirimir las diferencias o conciliarlas, "sin cuyo requisito previo y constancia legal de no haber bastado este arbitrio, ningún Tribunal del Estado podrá oír, ni dar curso a las demandas" (artículo 15). Igualmente se recogía textualmente lo referido a las causas criminales de los eclesiásticos por delitos perseguidos por las leyes de la república extrañas a la religión (artículo 16) y las facultades disciplinarias de los ordinarios (artículo 17).

El resto del articulado recoge textualmente las disposiciones del concordato boliviano, por lo que quedaba regulado según su modelo lo referido a los bienes (arts. 18-20), lo relativo a monasterios y regulares (artículo 21), misiones (artículo 22), juramento de obispos y demás eclesiásticos (artículo 23), oraciones por la república y el presidente (artículo 24), exenciones castrenses (artículo 25) y cláusulas finales (arts. 26-29).

\section{El concordato de 2 de julio de 1884.}

Rafael Carrera fue sustituido a su muerte, ocurrida en 1865, por el general Vicente Cerna, conservador con algunos resabios progresistas, que fue depuesto en junio de 1871 por el liberal Miguel García Granados, quien procedió a expulsar a los jesuitas, considerados enemigos de la libertad. Granados fue expulsado por el general Justo Rufino Barrios en 1873, quien permaneció en el poder hasta su muerte en 1885. Durante su gobierno se proclamó el matrimonio civil obligatorio, se secularizaron los cementerios, se fomentó la enseñanza laica y se propugnó la libertad de prensa; fueron también abolidas las órdenes religiosas masculinas, se suprimió el privilegio del fuero y fueron confiscados los bienes de las manos muertas. En 1879 se promulgó una Constitución liberal que vino a sancionar todas estas medidas $^{20}$. En este clima, sin embargo, fue suscrito un nuevo concordato, el

${ }^{20}$ Arjona Colomo, Miguel, cit. (n. 5), II, p. 139; Minnerath, Roland, L'Église et les États, cit. (n. 1), p. 436; EL MISMO, L'Église catholique, cit. (n. 1), pp. 55-56; SÁNCHEZ, Luis Alberto, cit. (n. ), II, pp. 274-275; Estrada Monroy, Agustín, Noticia cronológica de las leyes emitidas en Guatemala tocantes a la religión y a la Iglesia católica, en Estudios Teológicos 7 (Guatemala, 1980), 14, pp. 17-36; Miller, Hubert J., La Iglesia y el Estado en tiempo de Justo Rufino Barrios (Guatemala, Universidad de San Carlos de Guatemala, 1976). 
que fue integrado por un intercambio de notas. Estamos ya en el pontificado de León XIII, pero este concordato de celebró antes de la encíclica Immortale Dei $(1885)^{21}$ en la que quedaría plasmada la visión leonina de las relaciones entre la Iglesia y el Estado. Su influjo se vería poco después en el concordato celebrado con Colombia a fines de 1887.

Se iniciaba el texto con una declaración general según la cual el Santo Padre, en su apostólica solicitud, habiendo tomado en consideración la triste condición por la que atravesaba la iglesia de Guatemala, si dirigía al gobierno para establecer, de común acuerdo, las providencias oportunas. Por su parte, el presidente de la república, secundando la paternal solicitud del papa, de buena gana se mostraba dispuesto a remover los obstáculos que se oponían a la concordia y buena armonía de las dos supremas autoridades, por lo que se había llegado a la determinación de establecer algunos acuerdos dirigidos a proveer las necesidades más urgentes de la Iglesia y abrir la vía para ulteriores inteligencias en el futuro.

Repitiendo lo que ha se había acordado en el primer concordato, se garantizaba a los obispos, al clero y a los fieles la libre comunicación con la Sede Apostólica, en atención a que el Romano Pontífice, por derecho divino, ejercía el primado de jurisdicción sobre toda la Iglesia (núm. 1). De la misma manera, el ordinario podría libremente dirigir al clero y gobernar la Iglesia, y ejercitar el ministerio propio según la vigente disciplina aprobada por la Santa Sede (núm. 2).

Había una regulación expresa de los seminarios, de manera que en la diócesis de Guatemala se restablecería el seminario diocesano según las normas del Concilio de Trento, dependiendo sólo del prelado diocesano la admisión y exclusión de los alumnos, el nombramiento y remoción de los profesores y dirigentes, y cuanto pertenecía a la enseñanza, disciplina, régimen y administración del instituto, libertad que se garantizaba también respecto de los establecimientos dedicados a la educación e instrucción del clero (núm. 3). El seminario sería erigido en el edificio conocido como Colegio de Infantes, debiendo el gobierno contribuir a los gastos de ampliación y restauración para el nuevo destino que se le daba (núm. 5); y para el mantenimiento del mismo, se restablecería la cuota parroquial conocida como Cuartas de Colegio (núm. 6). Complementaba lo anterior el reconocimiento de que los grados académicos en materia eclesiástica conferidos con autoridad de la Santa Sede o del ordinario, cuando estaba competentemente autorizado por la misma, tendrían valor legal reconocido por el gobierno (núm. 4).

En materia de nombramientos, según el concordato, la sede metropolitana sería provista por el Sumo Pontífice motu proprio (núm. 7). Pero en el intercambio de notas, en la respuesta del cardenal secretario de Estado al ministro, se aseguraba que, antes de nombrar al arzobispo de Guatemala, se tomarían las oportunas diligencias con el presidente de la república para que la elección no recayese sobre un sujeto que, por hechos políticos, inspirase fundado temor de perturbación del orden público. Se definía en el concordato la composición del

${ }^{21}$ Su texto en Gasparri, card. Petrus (ed.), Codicis Iuris Canonici Fontes, III: Romani Pontifices a. 1867-1917 (Typis Polyglottis Vaticanis, 1933), pp. 234-250, Nº 592. En castellano, Guerrero, Fernando (dir.), El magisterio pontificio contemporáneo (Madrid, Bac, 1992), II, pp. 444-460. 
capítulo catedralicio de Guatemala y la intervención que en el nombramiento de sus integrantes correspondía al presidente de la república (núms. 8-9). Cuando vacare la sede metropolitana, el capítulo procedería libremente a la elección del vicario capitular, según las prescripciones del Concilio de Trento (núm. 10), norma que se repetía respecto del concordato de 1851 (núm. 13), si bien ahora nada se decía respecto del gobierno de los presentados. Y en la nota dirigida por el ministro guatemalteco al cardenal secretario de Estado, se aseguraba que el gobierno estaba dispuesto a dar salvoconducto, sin distinción de personas, a los eclesiásticos que se encontraban fuera del país y que acudieren a él pidiéndoselo.

Había un expreso reconocimiento que todos los miembros del clero estarían exentos de la obligación del servicio militar (núm. 11). Pero, quizá, lo más importante era el aspecto patrimonial, estableciéndose, en compensación por los bienes de que la Iglesia había sido privada, que el gobierno asumía la obligación de proveer a la conveniente dotación de la misma, suma que era reconocida por el gobierno como un verdadero crédito a favor de la Iglesia (núm. 12). Por su parte, el Santo Padre, siendo deferente a la petición del presidente de la república para proveer a la tranquilidad pública, saneaba la situación patrimonial de los bienes usurpados a la Iglesia en los años anteriores (núm. 13).

Finalizaba el acuerdo estableciendo que sería publicado como ley del Estado y su entrada en vigencia se produciría con la preconización y posesión del nuevo arzobispo (núm.14), si bien su ratificación se realizaría no más allá de quince meses, o antes si fuere posible (núm. 15).

Este nuevo concordato no suprimió los conflictos entra la Iglesia y el Estado, al punto que en 1887 fue exiliado el arzobispo. El 8 de febrero de 1898 tomó posesión del poder el abogado Manuel Estrada Cabrera, iniciando una dictadura de tipo civil que se prolongaría hasta 1919. Un hecho que lo retrata en sus relaciones con la Iglesia fue que hizo construir un templo a Minerva para las celebraciones nacionales. En estas circunstancias, el concordato de 1884 pronto cayó en el olvido.

\section{Concordato entre Pío IX y la República de Haití DE 28 DE MARZO DE $1860^{22}$}

Desde la independencia, Haití padeció una serie de gobiernos autárquicos, en que no faltaron ni negros ni mulatos y hasta conoció una experiencia imperial con Faustín I, un ex esclavo que gobernó entre 1847 y 1859 . Durante esos años Haití se convirtió en un lugar al que acudían todos los sacerdotes en situación irregular, de vida escandalosa, en rebeldía con sus prelados. A Faustín I le sucedió el general Nicholas Fabre Geffrad, ni negro ni mulato, que se mantuvo en la presidencia hasta el 13 de mayo de 1867, años en los que restauró la república respetando la Constitución, consiguiendo el reconocimiento de Estados Unidos y restableciendo

${ }^{22} \mathrm{Su}$ texto en Enchiridion, cit. (n. 4), pp. 304-315, N 581-603; también en Mercati, Angelo, cit. (n. 14), I, pp. 929-936. Es español, en Corral Salvador, Carlos; Giménez MarTínEZ Carvajal, José, Concordatos vigentes (Madrid, Fundación Universitaria Española, 1981), II, pp. 497-513. 
las relaciones con la Santa Sede mediante la firma del concordato en 1860. Esto trajo como consecuencia que llegaron al país sacerdotes que, aunque pocos en número, lograron conquistar a la élite, estableciendo centros de enseñanza ${ }^{23}$.

Haití tiene una historia que la separa de la tradición hispánica y la acerca a la francesa, por lo que, a diferencia de los concordatos de Costa Rica y el primero de Guatemala, que habían seguido de cerca el concordato de Bolivia, el celebrado por la Santa Sede con la República de Haití siguió de cerca el modelo del concordato celebrado en 1801 por Napoleón ${ }^{24}$, lo que quedaba expresado desde el primero de sus artículos que, según el modelo francés, afirmaba que: "la religión católica, apostólica y romana, que es la religión de la gran mayoría de los haitianos, estará especialmente protegida, asi como sus ministros, en la República de Haití y gozará de los derechos y atribuciones que le son propios" ${ }^{25}$. Con todo, había normas de este concordato que se encontraban también en los concordatos latinoamericanos que ya se habían firmado, a saber, la libertad de los arzobispos y obispos para gobernar los seminarios (artículo 7), la libre comunicación de los obispos, clero y fieles con la Santa Sede y de los obispos con sus diocesanos (artículo 13), las oraciones al término de los oficios divinos por la república y el presidente, a las que se agregaba otra según la cual se pedía que Dios los escuchara el día que lo invocaran -"Et exaudi nos in die qua invocaverimus te" (artículo 15)-. Hay, sin embargo, particularidades que lo separaran de los concordatos anteriores.

En relación con los arzobispos y obispos, se definía que la ciudad de Puerto Príncipe, capital de la república de Haití, era erigida en arzobispado, debiendo ser establecidas lo antes posible las diócesis que dependerían de esta metropolitana, así como otros arzobispados y obispados si era necesario; las respectivas circunscripciones serían reguladas por la Santa Sede, de acuerdo con el gobierno de Haití (artículo 2), el que se obligaba a acordar y mantener a los arzobispos y obispos un tratamiento anual conveniente según los fondos del tesoro público (artículo 3), lo que se aplicaba, según la nota integrativa del plenipotenciario haitiano, a los titulares y al gran vicario o vicario capitular cuando gobernaran las diócesis por deceso o dimisión del titular. Nada se decía del derecho de patronato, pero se reconocía que el presidente de Haití gozaría del privilegio de nombrar los arzobispos y obispos, quienes no podrían ejercer su jurisdicción antes de recibir la institución canónica; y en los casos en que la Santa Sede creyere un deber aplazar o no conferir esta institución, informaría de ello al presidente de Haití quien, en este último caso, nombraría a otro eclesiástico (artículo 4).

Los arzobispos y arzobispos, antes de entrar en el ejercicio de su ministerio

${ }^{23}$ Arjona Colomo, Miguel, cit. (n. 5), pp. 113-114; De Echeverría, Lamberto, Haití, en Corral Salvador, Carlos; Giménez Martínez Carvajal, José, cit. (n. 22), pp. 495-496; Minerath, Roland, L'Église et les États, cit. (n. 1), p. 437; El mismo, L'Église catholique, cit. (n. 1), p. 56; SÁnCHeZ, Luis Alberto, cit. (n. 5), pp. 279-281. Lit.: Robert, Paul, L'Église et la première république noire (Rennes, s.a. [pero 1967]).

${ }^{24} \mathrm{Su}$ texto en Enchiridion, cit. (n. 4), pp. 3-9, № 1-19. En castellano en SANTOS Díez, José Luis; Corral Salvador, Carlos, Acuerdos entre la Santa Sede y los Estados. Versión española de los textos (Madrid, Bac, 2006), pp. 419-422.

${ }^{25}$ El concordato francés se abre con la afirmación de que: "el gobierno de la República francesa reconoce que la religión católica, apostólica, romana es la religión de la mayoría de los franceses". 
pastoral, debían prestar juramento directamente entre las manos del presidente de la república, el que debía ser prestado, también, por los vicarios generales, los curas y los vicarios de parroquias, así como todos los otros miembros de la jerarquía eclesiástica, todos los jefes de escuelas o instituciones religiosas antes de ejercer sus oficios, los que prestaría el juramento entre las manos de la autoridad civil designada por el presidente de Haití (artículo 5 inc. $2^{\circ}$ ).

El arzobispo o los obispos podían instituir para el bien de su diócesis, después de un acuerdo previo con el presidente de Haití o sus delegados, un capítulo compuesto por un número conveniente de canónigos, conforme a las disposiciones del derecho canónico (artículo 6). También nombrarían sus vicarios generales. Produciéndose la muerte o la dimisión del arzobispo u obispo, no habiendo cabildo eclesiástico, la diócesis sería administrada por el vicario general que uno u otro hubiesen designado como tal; en defecto de esta designación, la administración correspondería a quien fuese el más antiguo en el oficio de vicario general. Todos los otros vicarios, si los hubiere, ejercerían sus funciones bajo la dependencia de este vicario y esto: "en virtud del poder extraordinario acordado a este efecto por la Santa Sede”. Existiendo un capítulo catedralicio, a él le correspondería nombrar al vicario capitular, de acuerdo con las prescripciones canónicas (artículo 8). Igualmente los arzobispos y obispos nombrarían a los curas párrocos y a sus vicarios, así como a los miembros de los capítulos que les correspondían, nombramientos que se harían conforme a las leyes canónicas (artículo 9). Pero en la nota integrativa del ministro plenipotenciario a Haití se agregaba que dichos nombramientos no podrían realizarse sino en personas aceptadas por el presidente de la república. Y si era necesario hacer cambios en las circunscripciones parroquiales o erigir nuevas, los arzobispos y obispos podrían hacerlo, concertándose a este efecto, con anterioridad, con el presidente de Haití o sus delegados (artículo 11). También correspondía a los arzobispos y obispos examinar las letras de los eclesiásticos extranjeros que fueren al país a ejercer su ministerio (artículo 8).

Tanto los arzobispos y obispos, para el régimen de sus iglesias, serían libres para ejercer todo lo que les correspondía según las normas canónicas (artículo 10), pero ello en el entendido, según la nota integrativa del plenipotenciario haitiano, que no podría en ningún caso interpretarse de manera de perjudicar en nada los derechos y atribuciones propias de la autoridad temporal; en la nota del cardenal secretario de Estado se hacía presente que los arzobispos y obispos, ejerciendo su ministerio pastoral conforme a las prescripciones canónicas y a la disciplina en vigor aprobada por la Santa Sede, no podrían nunca dar lugar a algún perjuicio a los derechos y atribuciones de la autoridad temporal, pues la Santa Sede no tenía nada tanto en el corazón como ver a las dos autoridades ejercerse de común acuerdo, en los límites de sus atribuciones respectivas, y conservar una armonía perfecta, que no podía sino que fortificarlas una a la otra en interés del bien.

En lo referido a las órdenes religiosas, en interés y adelanto espiritual del país se podrían instituir órdenes y establecimientos religiosos aprobados por la Iglesia, todos los cuales serían instituidos por los arzobispos u obispos que se pondrían de acuerdo, con anterioridad, con el presidente de Haití o sus delegados (artículo 12). Y desde la perspectiva patrimonial, los fondos de las curias serían empleados 
en cada parroquia en el mantenimiento del culto y de sus ministros así como los seminarios y otros establecimientos píos. La administración de estos fondos sería confiada, bajo la alta vigilancia del arzobispo o del obispo diocesano, a los curas párrocos y al director del consejo de notables, los que escogerían un cajero entre los ciudadanos del lugar (artículo 14).

De parte del presidente de Haití se declaraba que estaba bien entendido por la Santa Sede que la ejecución de todo lo que quedaba estipulado en el concordato no podría ser dificultado por ninguna disposición de las leyes de la república o alguna interpretación contraria de dichas leyes o usos en vigencia (artículo 16). Por su parte, todos los puntos concernientes a materias eclesiásticas no mencionados en el concordato serían regulados conforme a la disciplina vigente en la Iglesia y aprobada por la Santa Sede (artículo 17), en el entendido, agregaba la nota integrativa del plenipotenciario de Haití, que nunca podrían dar lugar a algún perjuicio a derechos y atribuciones de la autoridad temporal. El concordato sería ratificado por ambas partes y el intercambio de ratificaciones se haría en Roma o París, en el plazo de seis meses y antes si ello era posible (artículo 18). La nota integrativa del cardenal Antonelli, secretario de Estado de Pío IX, finalizaba aclarando que en el caso de que uno de los sucesores de los presidentes de Haití no profesare la religión católica, el concordato sería modificado en cuanto a los derechos que son atribución de un jefe de Estado católico y que no podrían ser ejercidos por un jefe que profesare otra religión.

Desde la firma de este concordato las relaciones entre la Iglesia y el Estado han sido reguladas por este concordato y sus notas integrativas. Para la ejecución del mismo se concluyó un convenio el 6 de febrero de $1861^{26}$, por el que se procedió a la organización territorial de la República en cinco diócesis, tomando como base la división política y civil del país, incluida la suficiente dotación estatal; y con el mismo fin, el 17 de junio de $1862^{27}$ se firmó un nuevo convenio por el que se fijaba las asignaciones del clero y la intervención del mismo en la instrucción pública, así como la ayuda al mantenimiento del seminario menor y a la formación de los candidatos al sacerdocio. Con no pocas dificultades, incluida una denuncia formal en 1881, este concordato, complementado con nuevos convenios, sigue vigente.

\section{Concordato entre Pío IX y el presidente de la República de} HONDURAS DE 9 DE JULIO DE $1861^{28}$

Honduras obtuvo su independencia absoluta el 5 de noviembre de 1838 a partir de la cual se inició una larga lista de presidentes, caracterizados por un caudillismo nocivo para la nación, salvo alguna administración en el sentido normal, una de

\footnotetext{
${ }^{26}$ Su texto en francés y español en Corral Salvador, Carlos; Giménez Martínez Carvajal, José, cit. (n. 22), pp. 515-521.

${ }^{27} \mathrm{Su}$ texto en francés y español ibíd., pp. 523-527; también en Enchiridion, cit. (n. 4), pp. 368-373, Nº 695-705.

${ }^{28} \mathrm{Su}$ texto en Enchiridion, cit. (n. 4), pp. 314-333, N 604-635; también en Mercati, Angelo, cit. (n. 14), I, pp. 936-948.
} 
las cuales fue la del general Santos Guardiola, caudillo conservador que gobernó entre 1856 y 1862, que mantuvo la libertad de prensa y de sufragio y observó el más amplio respeto por los derechos individuales. Durante su mandato se firmó el concordato con la Santa Sede, no obstante lo cual, al año siguiente, 1862, decretó la libertad de creencias y de culto ${ }^{29}$.

Este concordato volvió a la tradición de los concordatos que tuvieron como modelo el concordato con Bolivia al que siguió de cerca, incluso en la distribución de las materias y el número de artículos, de manera que las disposiciones de aquél, salvo la particularidad que señalo a continuación, hay que entenderlas reproducidas en este acuerdo con la república centroamericana. De esta manera, la religión católica "es la religión del Estado" (artículo 1) con las mismas consecuencias ya vistas en relación con la enseñanza (artículo 2) y la censura (artículo 3); se declaraba la libre comunicación de obispos, clero y pueblo con el papa (artículo 4). La única innovación se produce en relación con el pago del diezmo que el gobierno de Honduras se comprometía a conservar y a obligar autoritativamente a él, destinado en su totalidad a cubrir las dotaciones del obispado, cabildo y seminario y para los gastos del culto y fábrica de la catedral y demás edificios eclesiásticos. "Las pujas que hubiesen en los remates se destinarán a la promoción de establecimientos de enseñanza y beneficencia pública”. Para el caso que los diezmos no fueren suficientes para cubrir los indicados gastos, el gobierno se comprometía a cubrir anualmente el déficit. En todo caso, la recaudación de los referidos diezmos y su inversión estaría siempre a cargo de una junta de eclesiásticos presidida por el ordinario o por el vicario capitular en sede vacante. Y si por circunstancias que no podían ser previstas debieran abolirse lo diezmos o hacer variaciones en ellos, no podría hacerse sino con la intervención de la Santa Sede, sustituyendo de cuenta del gobierno otros fondos de modo que formaren una renta decorosa e independiente, de verdadera propiedad de la Iglesia (artículo 5). Como en los otros concordatos, los párrocos seguirían percibiendo las primicias y los derechos de estola hasta que el gobierno les asignare una congrua segura e independiente (artículo 6). En todo lo demás el concordato hondureño reproduce el concordato con Bolivia, incluida la fórmula del juramento de los eclesiásticos (artículo 22) y los artículos finales.

Complementó el concordato un intercambio de notas entre el cardenal secretario de Estado y el enviado extraordinario y ministro plenipotenciario de Honduras, en las que el cardenal, en relación con el artículo 5 del concordato, en vista de las explicaciones que proporcionaba el mismo artículo y tomando en consideración que el gobierno se obligaba a cubrir el déficit que pudiere resultar en el presupuesto eclesiástico, la Santa Sede no veía ninguna dificultad en que el director general de la renta publica del gobierno de Honduras asistiere como vocal a la comisión eclesiástica encargada de la cobranza y administración del diezmo; al mismo tiempo declaraba que la nota debía hacer parte del concordato, lo que era ampliamente aceptado por el plenipotenciario hondureño en su nota.

${ }^{29}$ Arjona Colomo, Miguel, cit. (n. 5), p. 131; Minerath, Roland, L'Église et les États, cit. (n. 1), p. 437; El mismo, L'Église catholique, cit. (n. 1), p. 57; SÁNCHEZ, Luis Alberto, cit. (n. 5), pp. 279-281. 
Santos Guardiola murió asesinado por su propia guardia personal en enero de 1862, con lo que se inició un decenio de anarquía al término del cual llegaron los liberales al poder, iniciando una política anticlerical consagrada en la Constitución aprobada en 1880 que, junto con confirmar la libertad de cultos, prohibió a los sacerdotes ocupar cargos públicos e impuso la enseñanza laica en los colegios del Estado. Mediante leyes complementarias se derogaron los privilegios del clero y el diezmo, se disolvieron las congregaciones religiosas, se confiscaron los bienes de la Iglesia, de los conventos y de las cofradías, se establecieron el matrimonio civil y el registro civil, junto al divorcio y los cementerios laicos y se cerró la universidad ${ }^{30}$. Superado el concordato por los hechos y la nueva legislación, el mismo año 1880 fue denunciado y cesó su vigencia.

\section{Concordato entre Pío IX y el presidente de la República de NiCARAGUA DE 2 DE NOVIEMBRE DE $1861^{31}$}

El apoyo que los liberales habían dado a William Walker, filibustero norteamericano con ambiciosas pretensiones en Centroamérica, quien finalmente fue fusilado en 1860, los desacreditó políticamente lo que permitió que durante los siguientes 30 años fueran los conservadores los que gobernaron en Nicaragua, sucediéndose entre 1857 y 1893 ocho presidentes por un período constitucional de cuatro años. Esta consolidación política permitió mantener la paz interna, con situaciones excepcionales de violentos reclamos de los indígenas por la explotación de que eran objeto. Fue en este ambiente en que se firmó el concordato con la Santa Sede ${ }^{32}$.

Separado por menos de cuatro meses con el concordato con Honduras, el concordato con Nicaragua siguió la tradición de los concordatos anteriores inspirados en el concordato boliviano, y fue firmado, de parte de la Santa Sede, por el mismo cardenal secretario de Estado que había participado en todos ellos, el cardenal Jacobo Antonelli. Sin embargo, en el caso de Nicaragua, su articulado se elaboró a partir del concordato con Costa Rica que, aún conservando los mismos contenidos que el concordato boliviano, cambió el orden de algunos artículos, que fue el orden seguido por el concordato nicaragüense, lo que significó que, de 29 artículos del modelo boliviano, pasaron a 28 como sucedía en el concordato con Costa Rica.

A la luz de lo anterior, siendo el concordato de Nicaragua una copia casi textual del concordato con Costa Rica, el que, a su vez, fue una copia reordenada en algunos aspectos del concordato boliviano, no es menester describir el nicaragüense pues sus contenidos ya los conocemos. Hay algunos otros cambios menores, como

\footnotetext{
${ }^{30}$ Krebs W., Ricardo, La Iglesia de América Latina en el siglo XIX (Santiago, Ediciones Universidad Católica de Chile, 2002), pp. 215-216.

${ }^{31} \mathrm{Su}$ texto en Enchiridion, cit. (n. 4), pp. 332-351, N 636-665; también en MerCati, Angelo, cit. (n. 14), I, pp. 948-959.

${ }^{32}$ Arjona Colomo, Miguel, cit. (n. 5), p. 135; Krebs W., Ricardo, cit. (n. 30), pp. $213-$ 215. Lit.: Arellano, Jorge Eduardo, Breve historia de la Iglesia en Nicaragua (1523-1979) (Managua, 1981).
} 
en el uso de algunas expresiones ${ }^{33}$, o menciones expresas a algunas particularidades de Nicaragua ${ }^{34}$, pero estos no alteraron en nada los contenidos.

Durante la vigencia del concordato hubo algunos momentos de tensión, como el suscitado en 1868 por la presentación hecha por el gobierno al obispado de León que se encontraba vacante, de un candidato que no agradó al cabildo el que se opuso, triunfando finalmente la propuesta del gobierno; o la expulsión de los jesuitas en 1881. No obstante estas situaciones puntuales, hubo entendimiento entre la Iglesia y el Estado. Con la llegada al poder del liberal José Santos Zelaya este buen entendimiento llegó a su fin. En 1894 promulgó una nueva Constitución en la que se impuso la separación entre la Iglesia y el Estado y la abolición de las posesiones de manos muertas, la educación laica, el matrimonio civil y los cementerios laicos. El mismo año, el concordato dejó de estar en vigor ${ }^{35}$.

\section{Concordato entre Pío IX y el presidente de la República de San Salvador de 22 de abril de $1862^{36}$}

La independencia de El Salvador fue proclamada en febrero de 1841, y con ello se inició un período de guerras externas contra Guatemala, Honduras y Nicaragua, y una serie de revoluciones internas que se sucedieron continuamente. Tampoco faltaron los incidentes con la Iglesia, al punto que el primer obispo de San Salvador, cuyo obispado había sido erigido en 1842 por Gregorio XVI (18311846) y el obispo nombrado en 1843 , fue expulsado en 1846, el mismo destino que tuvo que padecer su sucesor quien, no obstante, regresó del destierro y pudo intervenir en la elaboración del concordato. En los años siguientes entraron en el país los capuchinos, los jesuitas y sacerdotes seculares ${ }^{37}$.

El concordato con San Salvador fue firmado cinco meses después del celebrado con Nicaragua, interviniendo nuevamente en su elaboración y firma por parte de la Santa Sede el cardenal Jacobo Antonelli, secretario de Estado de Pío IX. Se situó en la misma línea que los celebrados con anterioridad, esto es, siguió el modelo boliviano, pero según la distribución de materias que hizo el concordato con Costa Rica que ya hemos visto y cuyo contenido doy por reproducido. Sin perjuicio de las adecuaciones propias a las particularidades del nuevo país ${ }^{38}$,

\footnotetext{
${ }^{33}$ Como sustituir en el artículo 4 "Santa Sede" por "S. Sede Apostólica"; o en el artículo 7 "En vista de" por "En atención a".

${ }^{34} \mathrm{En}$ el artículo 10, cuando se reconoce el derecho de la Santa Sede de erigir nuevas diócesis y la obligación del gobierno de dotarlas adecuadamente, se dice que en ellas "se procederá sobre las bases adoptadas para la Catedral de la Asunción de Na Sa la Virgen María en la República de Nicaragua".

${ }^{35}$ Minerath, Roland, L'Église et les États, cit. (n. 1), p. 437; El mismo, L'Église catholique, cit. (n. 1), p. 57; KREBS W., Ricardo, cit. (n. 30), pp. 213-215.

${ }^{36} \mathrm{Su}$ texto en Enchiridion, cit. (n. 4), pp. 350-367, N 666-694; también en Mercati, Angelo, cit. (n. 14), I, pp. 960-970.

${ }^{37}$ Arjona Colomo, Miguel, cit. (n. 5), pp. 146-147; Gran Enciclopedia Rialp Ger, (7a edición, Madrid, Ediciones Rialp S.A., 1993), VIII s.v. "El Salvador. Historia de la Iglesia”.

${ }^{38}$ Como la referencia a la "diócesis de San Salvador" en el artículo 7; o al "Gobierno del Salvador" en el artículo 10.
} 
hay sólo un cambio de contenido, pues el concordato salvadoreño suprimió el artículo 21 del concordato costarricense, según el cual el gobierno suministraría los medios adecuados para la propagación de la fe y conversión de los infieles existentes en su territorio, así como favorecería el establecimiento y progreso de las misiones autorizadas por la Congregación de Propaganda Fide, para que su "laudable objeto" llegase a todo el territorio de la república. La supresión de este artículo, que aparece en todos los otros concordatos, hizo que el número total de artículos fuese sólo de 27 artículos.

Durante el gobierno conservador del presidente Francisco Dueñas (18631871), que accedió al poder en 1863, las relaciones con la Iglesia fueron estables y cumplió los compromisos que había asumido el gobierno según el concordato. La guerra con Honduras, en marzo de 1871, trajo la caída de Dueñas y su reemplazo por el general liberal Santiago González (1871-1876), iniciándose una postura anticatólica con decisiones como la secularización de los cementerios, la expulsión de los jesuitas y de los obispos, confiscación de los bienes eclesiásticos, prohibición de órdenes religiosas para, finalmente, decretar la abrogación del concordato ${ }^{39}$.

\section{Concordato entre Pío IX y la República de Venezuela} DE 26 DE JULIO DE $1862^{40}$

El 28 de julio de 1824 el general Francisco de Paula Santander estableció el patronato, que fue declarado vigente en la Constitución de 1830 y, si bien la jerarquía protestó de la fuerte intervención del Estado en la organización de la Iglesia, en los nombramientos y en la administración de los bienes eclesiásticos, la intervención del Estado en los asuntos eclesiásticos fue intensa. Hubo intentos de celebrar un concordato bajo el pontificado de Gregorio XVI, pero no se pudieron celebrar por no aceptar la Santa Sede la posición venezolana de que el patronato era un atributo inherente a la soberanía. Con Pio IX continuaron las gestiones hasta que el concordato pudo firmarse durante la dictadura de José Antonio Páez (18611863), en el que, si bien subsistía el patronato, es entendido como una concesión del Romano Pontífice y, en general, es bastante favorable a la Iglesia ${ }^{41}$.

El concordato celebrado entre la Santa Sede y la república de Venezuela, firmado nuevamente por parte de la Santa Sede por el mismo cardenal secretario de Estado, Jacobo Antonelli, no se apartó de los concordatos anteriores en cuanto a su contenido, siguiendo la huella iniciada por el concordato boliviano, pero, junto a algunos artículos que repiten el texto boliviano, hay otros que son modificados y aún se agregan algunas disposiciones nuevas, al punto que el contenido total de este concordato está distribuido en 31 artículos, siendo, en consecuencia, el más

${ }^{39}$ Minerath, Roland, L'Église et les États, cit. (n. 1), p. 437; El mismo, L'Église catholique, cit. (n. 1), p. 57; KREBS W., Ricardo, cit. (n. 30), pp. 211-213.

${ }^{40} \mathrm{Su}$ texto en Enchiridion, cit. (n. 4), pp. 372-387, N 706-737; también en MERCATI, Angelo, cit. (n. 14), I, pp. 971-983.

${ }^{41}$ Arjona Colomo, Miguel, cit. (n. 5), pp. 30-31; Petschen, Santiago, Venezuela, en Corral Salvador, Carlos; Giménez Martínez Carvajal, José, cit. (n. 22), II, pp. 639-641; Sánchez, Luis Alberto, cit. (n. 5), pp. 293-300. 
extenso de los firmados hasta el momento. También se innovaba en cuanto a la distribución de las materias de manera que, aun cuando se conservaba a veces la redacción de los artículos, su ubicación en el texto era diferente.

El primer artículo, al igual que en todos los anteriores, afirmaba que: "la Religión católica apostólica romana continuará siendo la Religión de la República de Venezuela, y el Gobierno reconoce el deber de defenderla y conservarla eficazmente con todos los derechos y prerrogativas que le corresponden por la ordenación de Dios y sanciones canónicas". Es de notar que por primera vez un gobierno se comprometía a través del concordato, en lo que a la religión católica se refiere, a "defenderla y conservarla". Esta confesionalidad del Estado, al igual que en los concordatos anteriores, suponía la intervención de los obispos en la enseñanza, en una norma que, presentaba algunas variantes de redacción respecto de su modelo (artículo II). El artículo que sigue (artículo III) repetía lo referido a la conservación de los seminarios y a la autoridad que le correspondía al obispo en ellos, independiente del Estado; el artículo IV, con leves retoques de redacción ${ }^{42}$, repetía el derecho de censura que correspondía a los obispos, y el artículo $\mathrm{V}$, con retoques de redacción, reconocía la libre comunicación con Roma.

El artículo VI de Venezuela, que equivalía al artículo 5 de Bolivia, dejaba constancia que el gobierno de Venezuela, por intermedio de su ministro plenipotenciario había pedido y obtenido de la Sede Apostólica, "en atención a las circunstancias extraordinarias de los tiempos y lugares" que se sustituyesen los diezmos por una "asignación eclesiástica" que el gobierno se obligaba a pagar. En el mismo artículo se agregaba que: "los párrocos continuarán gozando del derecho de percibir las primicias y los emolumentos llamados de estola según la costumbre de cada diócesis". Era en atención a las obligaciones contraídas por el gobierno que el Sumo Pontífice concedía al presidente de la república: "el derecho de patronato y el privilegio de proponer los obispos, según los términos establecidos en la presente convención" (artículo VII), prohibiéndose el gobierno de los presentados y especificándose la manera de hacer la presentación (artículo VIII).

Se establecía un régimen diverso para el nombramiento de las dignidades y canonjías de las iglesias catedrales, si bien se reconocían derechos al presidente de la república (arts. X-XII). Con alguna reforma de redacción se regulaba el nombramiento de vicario capitular por el capítulo de la iglesia metropolitana o las sufragáneas vacantes, el cual debía "gobernar la diócesis durante el tiempo de la vacante" (artículo XIV). Lo mismo sucedía con la provisión de las parroquias (artículo XV), pero se agregaba un breve artículo según el cual "los coadjutores de las iglesias parroquiales serán elegidos exclusivamente por los ordinarios, previo examen sinodal' (artículo XVI). Se reconocía, también, el derecho de la Santa Sede de erigir nuevas diócesis (artículo XVII) y nuevas parroquias (artículo XVIII). Todos los eclesiásticos debían prestar juramento según la fórmula que se repetía en todos estos concordatos a partir del boliviano (artículo 23), con la aclaración

\footnotetext{
${ }^{42}$ Bolivia: "Los obispos conservarán asimismo su derecho de censura"; Venezuela: "Los obispos conservarán expedito el derecho de examinar y censurar". Bolivia: "y evitar toso lo que pudiera serle contrario"; Venezuela: "y para evitar todo lo que a ella se oponga".
} 
de que el gobierno no entendía "que quien lo preste quede obligado en conciencia a actos contrarios a las leyes de Dios y de la Iglesia" (artículo XXVII).

Lo referido a las causas de fe y similares era reconocido (artículo XIX) en los mismos términos que el concordato boliviano (artículo 14); en cambio, una norma especial en el concordato venezolano disponía que el fuero eclesiástico se conservaría en la república en las causas civiles de los clérigos; y en las criminales se conservaría el mismo fuero, "consintiendo la Santa Sede en que quede dentro de los límites a que hoy está reducido por las leyes civiles” (artículo XX). Se conservaban igualmente las facultades disciplinarias de los obispos para "corregir a los eclesiásticos que faltando a sus deberes no lleven una vida conforme a su estado" (artículo XXI), con una redacción diversa a su modelo boliviano (artículo 17).

En materia patrimonial, se reconocía que la Iglesia "conserva el derecho que tiene de adquirir y poseer bienes bajo cualquier justo título" (artículo XXII); se permitía que los bienes eclesiásticos estuviesen sujetos a impuestos, excepto las iglesias, seminarios y ciertos institutos dedicados al culto divino (artículo XXIII); se aseguraba que no serían inquietados quienes, por consecuencia de la ley civil de 11 de abril de 1833, habían dejado de pagar los diezmos, así como a los que había comprado desde 1810 bienes eclesiásticos, ni sus sucesores (artículo XXIV).

En cuanto a la vida consagrada, al igual que los demás concordatos que seguían al de Bolivia (artículo 21), en el de Venezuela se declaraba la conservación de los monasterios de monjas existentes a la fecha del acuerdo, pudiendo los ordinarios erigir otros "con entera libertad", y fundar conventos de religiosos "poniéndose de acuerdo con el gobierno" (artículo XXV). Y también el gobierno procuraría la conversión de los infieles y prestaría su cooperación y auxilio a las misiones enviadas por la Sagrada Congregación de Propaganda Fide (artículo XXVI). Se conservaban igualmente las oraciones por la república y el presidente como en el concordato boliviano (artículo 24) y los demás que se seguían, pero se cambiaba la fórmula, de manera que se permitía en la antigua oración Colecta "et famulos tuos" se mencionase el nombre del presidente de la república después de los del papa y obispo diocesano, diciéndose 'et Rempublicam nostram cum Praeside suo N.”.

Entre las normas agregadas, que no se encontraban en los concordatos anteriores, se afirmaba que quedaban vigentes "todas las disposiciones que hasta ahora han regido en la República de Venezuela relativas a espolios de los arzobispos y obispos" los que, en consecuencia, pertenecerían a las respectivas iglesias catedrales (artículo IX). También se disponía que, estando ya erigido en la diócesis de Guayana el capítulo catedral, con aprobación de la Santa Sede, se erigiría tan pronto como fuese posible el colegio seminario, según las normas del tridentino (artículo XIII). El concordato omitía toda referencia a los privilegios castrenses reglados en el concordato boliviano (artículo 25) y en los que le seguían, y finalizaba con los mismos artículos de los demás concordatos, aclarando de que, si ocurriere alguna dificultad sobre los puntos contenidos "en este Tratado", el papa y el presidente la resolverían "amigablemente de común acuerdo" (artículo XXX inc. 2), cláusula que no aparece en el concordato con Bolivia ni en los que le siguieron.

El concordato venezolano, el penúltimo firmado por Pío IX, fue un episodio de corta duración, porque la dictadura de Antonio Guzmán Blanco (1870-1877) 
desarrolló una política fuertemente anti eclesial y contraria a la Iglesia católica, estableciendo el matrimonio y el registro civil, los cementerios laicos, eliminando los monasterios, suprimiendo las escuelas católicas, eliminando el pago de las primicias, que había quedado como único ingreso económico regular para los párrocos, y la abolición del fuero eclesiástico, entre otros. El fanatismo de Guzmán Blanco lo llevó, incluso, a intentar una iglesia nacional, independiente de Roma, en la que los obispos serían elegidos por el Congreso y los párrocos por sus fieles ${ }^{43}$.

\section{Concordato entre Pío IX y el presidente de la República del Ecuador DE 26 de SEPTIEMBRE DE $1862^{44}$ Y SU NUEVA VERsión FIRMADA POR LEÓN XIII EL 2 DE MAYO DE $1881^{45}$}

\section{Concordato de 1862.}

Entre 1861 y 1875 Ecuador se configuró como un Estado católico modelo para el ultramontanismo de la mano del presidente Gabriel García Moreno que trató de conformar la legislación de país a las encíclicas de Pío IX. En los años anteriores se habían sucedido gobiernos liberales, conservadores y militares. Fue el último concordato latinoamericano firmado bajo el pontificado de este pontífice y el más favorable a los derechos de la Iglesia. Convencido de que el Ecuador debía constituirse como un Estado católico, García Moreno, una vez llegado a la primera magistratura en 1861, inició negociaciones con la Santa Sede para preparar un concordato, concluido el 26 de septiembre de 1862. En este esfuerzo de García Moreno por conformar la legislación ecuatoriana al magisterio pontificio, la Constitución de 1869 se situó en la misma línea del concordato, amenazando, por ejemplo, con pérdida de los derechos civiles a quien adhiriere a alguna sociedad secreta condenada por la Iglesia ${ }^{46}$.

Las materias tratadas en el mismo eran similares a las que se encontraban en los concordatos anteriores, pero en la mayoría de los casos se les daba un trato diferente; además, algunas de las contenidas en los concordatos anteriores no aparecían en el texto del concordato ecuatoriano, pero fueron tratadas en un intercambio de notas que hubo posteriormente entre ambos plenipotenciarios. Una vez más, actuó por la Santa Sede el mismo cardenal secretario de Estado, Jacobo Antonelli.

Como en los concordatos anteriores, el de Ecuador se abría con una declaración solemne en el sentido que la religión católica "continuará siendo la única religión de la República del Ecuador”, la que sería siempre conservada con todos los derechos y prerrogativas de que debía gozar según la ley de Dios y las disposiciones canónicas,

${ }^{43}$ Minerath, Roland, L'Église et les États, cit. (n. 1), p. 438; El mismo, L'Église catholique, cit. (n. 1), pp. 57-58; Krebs W., Ricardo, cit. (n. 30), pp. 223-233.

${ }^{44} \mathrm{Su}$ texto en Enchiridion, cit. (n. 14), pp. 386-413, N 386-413; MerCati, Angelo, cit. (n. 14), I, pp. 983-999.

${ }^{45} \mathrm{Su}$ texto en Enchiridion, cit. (n. 14), pp. 432-451, N 805-833; MerCATI, Angelo, cit. (n. 14), I, pp. 1001-1013.

${ }^{46}$ Minerath, Roland, L'Église et les États, cit. (n. 1), p. 438; El mismo, L'Église catholique, cit. (n. 1), p. 58; KREBS W., Ricardo, cit. (n. 30), pp. 233-238. 
a lo que agregaba una consecuencia que no estaba en los otros concordatos: "en consecuencia jamás podrá ser permitido en el Ecuador ningún otro culto disidente, ni sociedad alguna condenada por la Iglesia". Como en los concordatos anteriores, se aseguraba la existencia y autonomía de los seminarios, cuya disciplina dependía en todo del ordinario diocesano (artículo 2), así como la vigilancia, por parte de los obispos, de la instrucción de la juventud, a quienes les correspondía el derecho exclusivo de designar los textos para la enseñanza tanto de las ciencias eclesiásticas como de la instrucción moral y religiosa (artículo 3), y a cuidar que ninguna enseñanza fuere contraria a la religión católica y a la honestidad de las costumbres, para lo cual nadie podría enseñar en ningún establecimiento, público o privado, la teología, el catecismo o la doctrina religiosa sin haber obtenido autorización del prelado diocesano, quien podía revocarla cuando le pareciere oportuno; para los exámenes de los “institutores” primarios, el diocesano nombraría un asistente destinado a reconocer la instrucción religiosa y la conducta moral del examinado, el que no podría entrar en el desempeño de su oficio sin el asentimiento del mismo diocesano (artículo 4).

También se aseguraba la libre comunicación con el Romano Pontífice, pero con un añadido: "por tanto ninguna autoridad secular podrá poner obstáculos al pleno y libre ejercicio de dicha comunicación, obligando a los obispos, al clero y al pueblo a servirse del intermedio del gobierno para ocurrir en sus necesidades a la Sede Romana, o sujetando las bulas, los breves o los rescriptos de ésta al exequátur del gobierno" (artículo 5). De la misma manera se aseguraba la libertad de los ordinarios eclesiásticos para gobernar sus diócesis y para convocar y celebrar concilios provinciales y diocesanos -instituciones que no aparecían en ninguno de los concordatos anteriores- sin que se pusieran embarazos a la ejecución de sus providencias. "Asi pues, el gobierno del Ecuador dispensará su poderoso patrocinio y apoyo a los obispos, en los casos en que lo soliciten, principalmente cuando deben oponerse a la maldad de aquellos hombres que intenten pervertir el ánimo de los fieles y corromper sus costumbres" (artículo 6).

El papa concedía también el derecho de patronato al presidente, en virtud del cual éste podía proponer para los arzobispados y obispados, "sacerdotes dignos en el sentido de los sagrados cánones". Para tal efecto, sin embargo, inmediatamente que vacare una silla episcopal, el arzobispo pediría a los demás obispos sus votos para la provisión de la vacante, debiendo recoger los votos el obispo más antiguo cuando la silla vacante era la arzobispal; a quien le correspondiese, hecha la recolección de votos, debía presentar una lista de, al menos, tres candidatos, al presidente quien, eligiendo uno de ellos, lo propondría al Romano Pontífice. Para ello, los obispos tenían el plazo de seis meses, transcurrido el cual sin haberla hecho, la elección correspondía al presidente, quien, a su vez, tenía tres meses para la hacer la presentación, transcurridos los cuales, sin haberla hecho, la Santa Sede podía nombrar libremente al nuevo arzobispo u obispo. Cuando se trataba del nombramiento del primer obispo de un obispado de nueva erección, la propuesta la hacía directamente el presidente. Y, como en los concordatos anteriores, el propuesto no podía intervenir en el régimen o administración de las iglesias sin haber recibido antes las bulas de institución canónica (artículo 12). Una vez producida la 
vacante, el cabildo catedral, conforme a los decretos tridentinos, elegiría libremente al vicario capitular, sin que esta elección se pudiere revocar para proceder a una nueva elección, anulándose cualquier costumbre en contrario (artículo 15).

En virtud del patronato el presidente, como en los concordatos anteriores, también podía intervenir en el nombramiento de los miembros del cabildo catedral, si bien el concordato ecuatoriano ofrece particularidades, porque la primera dignidad sería de libre colación de la Santa Sede ${ }^{47}$; y serían de libre colación episcopal algunas prebendas (artículo 13). En cuanto a la provisión de las parroquias, los ordinarios, una vez cumplidas las exigencias del Tridentino, debían presentar al gobierno el nombre de tres eclesiásticos dignos, de entre los cuales el presidente, personalmente o por medio de sus delegados en las provincias, debía escoger a uno. El gobierno, por razones especiales, podía pedir la propuesta de otros tres nombres, lo que el ordinario podía hacer a condición de que esta segunda propuesta no se pudiera rechazar (artículo 14). Como contrapartida, el gobierno se obligaba a suministrar los medios oportunos para la propagación de la Fe y la conversión de los infieles existentes en el territorio, prestando el favor y ayuda al establecimiento y progreso de las misiones que se enviaren por autoridad de Propaganda Fide (artículo 22).

En uso de su propio derecho, la Santa Sede podría erigir nuevas diócesis y hacer nuevas circunscripciones en aquellas ya existentes (artículo 16) ${ }^{48}$. La división de las parroquias, cuando fuere necesario, se podía hacer de acuerdo con las autoridades locales (artículo 14).

Además de las órdenes y congregaciones religiosas ya presentes en el país, los ordinarios diocesanos podían, libremente y sin excepción, admitir y establecer en sus diócesis nuevas órdenes o institutos aprobados por la Iglesia, en conformidad a las necesidades de sus pueblos, a cuyo efecto el gobierno debía prestar su apoyo (artículo 20). En una nota complementaria del cardenal Antonelli, acerca de la inteligencia de algunos artículos del concordato, nota que debía entenderse parte integrante del concordato, el papa se hacía eco de la petición del gobierno para que tomase providencias eficaces en lo relativo a la inobservancia de la disciplina y abusos cometidos por los regulares, y expedía un decreto instituyendo una o más casas en cada orden religiosa en las que de debía observar siempre la vida común con la prescripción de la más estricta observancia de las propias constituciones, empleando medidas de rigor contra los religiosos incorregibles.

En lo que refería a los bienes temporales, como ya sucedía con los concordatos anteriores, se reconocía a la Iglesia "el derecho de adquirir libremente y por cualquier justo título" por lo que las propiedades que poseía y las que en el futuro poseyere le serían garantizadas por la ley. Es por lo que los bienes de fundación eclesiástica

${ }^{47}$ Salvo el concordato de Venezuela, en los anteriores no existía esta reserva; en el de Venezuela, la reserva sólo era para la primera dignidad del cabildo de la iglesia metropolitana de Caracas. El avance respecto de la Santa Sede es notorio.

${ }^{48} \mathrm{El} 30$ de septiembre de 1865 se celebró una convención entre la Santa Sede y Ecuador, en la que se aprobó el proyecto provisional para 1865 y 1866 así como el presupuesto permanente que regiría a partir de 1867 en adelante. Su texto en Enchiridion, cit. (n. 4), pp. 420-424, N 784-794; Mercati, Angelo, cit. (n. 14), I, pp. 1986-1088. 
de cualquier clase que fuesen, pertenecientes a hospitales y demás establecimientos de beneficencia que no estuvieren administrados por la autoridad eclesiástica les serían devueltos (artículo 19). Y como ya se decía en los concordatos anteriores, en cuanto a las antiguas y nuevas fundaciones eclesiásticas, no podría hacerse ninguna supresión o unión sin la intervención de la autoridad de la Santa Sede, salvada la facultad del obispo según el tridentino (artículo 19). Y también repitiendo lo ya establecido en los otros concordatos, la Santa Sede permitía que las personas y bienes eclesiásticos estuviesen sujetos a "los impuestos públicos" al igual que el resto de los bienes y ciudadanos, pero no era una autorización general, válida para siempre, como se puede entender en los otros concordatos, sino que la autoridad civil debía ponerse de acuerdo con la eclesiástica "para obtener la correspondientes autorización toda vez que la coacción sea necesaria", quedando exceptuados los seminarios, los bienes y cosas inmediatamente destinadas al culto y los establecimientos de beneficencia (artículo 9). Se conservaban los diezmos, pero el papa consentía que el gobierno continuase percibiendo la tercera parte "de los productos decimales", debiendo las autoridades civil y eclesiástica acordar un reglamento para la recaudación y administración de los diezmos (artículo 11).

Por decreto de 28 de mayo de 1836 se habían redimido por el gobierno los censos impuestos a favor de las causas pías, decreto que el concordato abolía; pero la Santa Sede, deseando proveer a la tranquilidad pública y remediar los males causados por la traslación de los censos al tesoro nacional, aseguraba que no habría molestias sobre el particular (artículo 17) y se fijaban los procedimientos para que el gobierno pagase las deudas contraídas (artículo 18).

En materia procesal, a diferencia de los concordatos anteriores, se abolían expresamente los recursos de fuerza, de manera que en cuanto a la ejecución y las sentencias pronunciadas por los jueces ordinarios eclesiásticos sólo se podría apelar de ellas a los tribunales superiores eclesiásticos o a la Santa Sede "según la disciplina establecida en el breve 'Exposcit' del Sumo Pontifice Gregorio XIII ${ }^{49}$ y conforme a las prescripciones canónicas, y particularmente en cuanto a las causas matrimoniales, a las que Benedicto XIV en la constitución 'Dei miseratione' ${ }^{50} o$ bien, hacer uso del recurso de nulidad o del de queja ante los mismos superiores". Por su parte, los jueces eclesiásticos pronunciarían sus juicios sin sujetarlos al dictamen previo de asesores seculares, a quienes, sin embargo, podrían consultar cuando lo creyeren oportuno, pudiendo desempeñar el oficio de asesores en estos juicios, los eclesiásticos que fueren abogados (artículo 7). En cambio, al igual que los concordatos anteriores, se afirmaba que las causas que miraban a la fe y sacramentos, incluidas las matrimoniales -las que no eran mencionadas en los concordatos anteriores- y las demás referidas a materias espirituales por razón de persona o materia, serían resueltas por los tribunales eclesiásticos, con excepción de las reservadas a la Santa Sede. "Lo propio se verificará en las causas civiles de los eclesiásticos y en las otras por delitos comprendido en el Código Penal de la República”, con lo cual este concordato se separaba de los concordatos anteriores en cuanto a las causas criminales, en los

\footnotetext{
${ }^{49}$ Del 15 de julio de 1583, en Gasparri, card. Petrus, cit. (n. 21), I, pp. 264-265, N ${ }^{\circ}$ 151.

${ }^{50}$ De 3 de noviembre de 1741, ibíd., pp. 695-701 Nº 318.
} 
que la Santa Sede aceptaba que fueren tramitadas ante los tribunales estatales. " $E n$ todos los juicios que sean de competencia eclesiástica, la autoridad civil prestará su apoyo y protección, a fin de que los jueces puedan hacer observar y ejecutar las penas y las sentencias pronunciadas por ellos" (artículo 8). Complementaba este artículo el intercambio de notas entre los plenipotenciarios, en el que, entre otros temas, el papa condescendía en que los eclesiásticos reincidentes quedasen privados del privilegio del fuero, concediendo a los jueces civiles las oportunas facultades para que pudieran aplicarles las penas impuestas en los cánones cuando cometieren algunos de los delitos como la embriaguez, concubinato, comercio u otros semejantes no expresados en el Código Penal del Estado.

En otra nota, declaraba el gobierno ecuatoriano que, en lo relativo al fuero de los eclesiásticos, tanto en las causas civiles como criminales por delitos comprendidos en el Código Penal, si graves razones o especiales circunstancias hicieren necesario una modificación o derogación del fuero, el gobierno no tomaría providencia sin antes obtener el consentimiento de la Santa Sede. Y si entre tanto, por algunos delitos políticos hubiese habido necesidad de tomar medidas contra los eclesiásticos delincuentes, el gobierno pediría la debida autorización al prelado diocesano para proceder contra los eclesiásticos con arreglo a las leyes vigentes. Continuaba la nota situándose en la circunstancia de que fuere preciso apresar el reo, en cuyo caso se haría "con cautela y circunspección debidas a la excelencia del estado clerical', de manera que los lugares de prisión serían siempre los conventos u otros lugares eclesiásticos, u otros distintos de las cárceles comunes. Y si la sentencia imponía la pena capital, se observarían en dicho caso las disposiciones canónicas. Se reconocía también el derecho de asilo, lo que no sucedía en los concordatos anteriores, lo que se hacía "por respeto a la majestad de Dios que es Rey de Reyes y Señor de Señores", para lo cual se respetaba la inmunidad de los templos en cuanto lo permitiesen la seguridad pública y las exigencias de la justicia, en cuyo caso la Santa Sede consentía que la autoridad eclesiástica diese, a solicitud de la autoridad civil, el permiso respectivo para la extracción de los refugiados (artículo 10).

En los artículos finales se disponía que después de los oficios divinos en todas las iglesias de la república debía decirse la siguiente oración: "Domine, salvam fac Rempublicam; Domine, salvum fac Praesidem eius" (artículo 21); que todo lo perteneciente a las personas y cosas eclesiásticas no previsto en el concordato, sería dirigido y administrado "según la disciplina canónica vigente en la Iglesia y aprobada por la Santa Sede" (artículo 23); la revocación de todo lo opuesto al concordato, debiendo considerarse el concordato como ley del Estado, poniéndose de acuerdo el papa y el presidente para resolver "amistosamente" las dificultades (artículo 24). La ratificación sería canjeada en el espacio de un año, o más pronto de ser posible (artículo 25).

Gabriel García Moreno fue asesinado el 6 de agosto de 1875. El concordato no sufrió cambios, pues su sucesor, un liberal moderado, dejó subsistir las leyes de García Moreno; pero fue destituido por un militar, dirigente de los radicales, el general Ignacio Veintimilla, quien actuó con dureza contra la Iglesia, suspendiendo el concordato el 28 de junio de 1877, restableciendo los derechos de patronato, medida que dio origen a fuertes protestas, las que fueron aumentando las pre- 
siones y abusos del gobierno, como el destierro de algunos obispos y sacerdotes, abusos que encendieron aún más las protestas, que llevaron a Veintimilla a ceder y restablecer el concordato en $1881^{51}$.

\section{Nueva versión de 1881.}

No se trató de un nuevo concordato sino de una nueva versión del que se había celebrado en 1862, por lo que conserva la misma estructura y reproduce textualmente algunos artículos o mejora la redacción de otros. Pero se introducen cambios en no pocos de ellos, siendo la tónica de todas estas modificaciones la de otorgar mayores derechos al Estado en asuntos eclesiásticos, de manera de aproximar esta nueva versión a los demás concordatos latinoamericanos. Así, por ejemplo, en la provisión de arzobispados y obispados, ya no cabía ninguna participación a los obispos en la presentación de candidatos al presidente para que éste eligiera uno de ellos para presentar a la Santa Sede, sino que el presidente, sin más, presentaría a la Santa Sede "eclesiásticos dignos e idóneos, en el sentido de los sagrados cánones, a fin de que el Sumo Pontifice les dé la institución canónica de obispos" (artículo XII). También en aquellos casos en que los obispos podían colacionar libremente algunas prebendas, ahora debían hacerlo "con aprobación del gobierno, que podrá rechazar a los que fueren presentados por razones de conveniencia política, comunicándolo a los diocesanos respectivos" (artículo XIII).

En la misma orientación de dar mayor injerencia al gobierno se sitúan algunas modificaciones en materia de bienes temporales; si bien la Iglesia siguió gozando del derecho de adquirir libremente y por cualquier justo título, ahora se exigía que ello ocurriera "conforme a las leyes de la República"; y los bienes eclesiásticos pertenecientes a comunidades y congregaciones religiosas no podrían ser enajenados "sin licencia de la S. Sede y permiso del gobierno" (artículo XIX). Tampoco podrían establecerse en el país nuevas órdenes o institutos aprobados por la Iglesia, a menos de que se hiciera "de acuerdo con el gobierno" (artículo XX). A lo anterior se agregaba una fuerte restricción al fuero eclesiástico (artículo VIII). En materia de diezmos, el gobierno se obligaba a conservarlo hasta que fuere sustituido con otra contribución de acuerdo con la Santa Sede (artículo XI).

Finalmente hubo algunas reformas al texto original del concordato que obedecían a las nuevas situaciones producidas especialmente con ocasión de las medidas anti eclesiales adoptadas por el gobierno de Veintimilla. Así, "los individuos que por causa de los pasados acontecimientos adquirieron del gobierno bienes pertenecientes a la Iglesia, o que sucedieren a los compradores en la posesión de los mismos, no serán jamás molestados en alguna cosa por este motivo, ni por parte del Sumo Pontifice reinante ni de sus sucesores".

El general Ventimilla fue destituido en 1884 y en los doce años siguientes la Iglesia pudo actuar libremente bajo los gobiernos de tres presidentes conservadores. De hecho, el 8 de noviembre de 1890 pudo celebrarse un nuevo acuerdo entre Ecuador y la Santa Sede para sustituir el diezmo, de acuerdo a lo que había

\footnotetext{
${ }^{51}$ KreBs, Ricardo, cit, (n. 30), pp. 236-237.
} 
establecido el artículo XI de la nueva versión del concordato ${ }^{52}$. Pero en 1895 se produjo un nuevo levantamiento liberal, cuyo triunfo significó el fin de los privilegios de la Iglesia, introduciendo en 1902 el matrimonio civil y decretando en 1904 la separación entre la Iglesia y el Estado.

\section{Xi. Concordato entre la Santa Sede y la República de Colombia DE 31 DE DICIEMBRE DE $1887^{53}$}

Fue el último concordato firmado en el siglo XIX entre la Santa Sede y un país de América Latina pero, a diferencia de los anteriores, tuvo una larga vigencia. Como fue una tónica generalizada en esa época, las primeras Constituciones colombianas establecieron el patronato, pero fue abolido en 1853 junto con el establecimiento de la separación de la Iglesia y del Estado, lo que hizo que fuera Colombia el primer Estado del continente latinoamericano en tomar esta medida. Se estableció el matrimonio civil obligatorio y el divorcio por común acuerdo, se suprimieron los diezmos y el fuero eclesiástico y se dispuso que los párrocos fuesen nombrados por los consejos municipales. En 1862 se confiscaron los bienes de la Iglesia y se suprimieron los conventos. A pesar de todo y sin perjuicio de todas estas medidas, la actividad de los clérigos era estrechamente controlada por el gobierno y ningún legado del papa podía ingresar al país. Una sangrienta guerra civil entre 1876 y 1877 permitió imponerse a los liberales lo que hizo que el parlamento aprobara nuevas leyes contra la Iglesia, pero una nueva revolución en 1885 hizo que los conservadores conquistaran el poder. Una nueva Constitución promulgada en agosto de 1886 reconoció la religión católica como religión oficial, lo que permitió que se celebrara un concordato con la Santa Sede el 31 de diciembre del año siguiente $e^{54}$.

Aunque el concordato con Ecuador de 1881 fue el primer concordato celebrado por León XIII con un país latinoamericano, como se trató de una nueva versión del celebrado en 1862, siguió el estilo de los concordatos pianos, si bien el ecuatoriano de 1862 no había seguido tan de cerca el modelo boliviano de los otros concordatos celebrados por Pio IX. El concordato con Colombia, en cambio, asume un nuevo estilo, consecuente con la nueva visión que León XIII da al tema de las relaciones entre la Iglesia y los Estados que poco antes había explicitado en la encíclica Immortale Dei, de $1885^{55}$.

${ }^{52}$ Su texto en Enchiridion, cit. (n. 4), pp. 534-544, No 1018-1036.

${ }^{53}$ Su texto en Enchiridion, cit. (n. 4), pp. 495-511, N 943-976; MerCaTI, Angelo, cit. (n. 14), I, pp. 1051-1069.

${ }^{54}$ KreBs, Ricardo, cit. (n. 30), pp. 217-223; Minnerath, Roland, L'Église et les États, cit. (n. 1), pp. 439-449; El MISMO, L'Église catholique, cit. (n. 1), pp. 58-59.

${ }^{55}$ Enc. Immortale Dei, 3: "La sociedad, por su parte, no está menos obligada que los particulares a dar gracias a Dios, a quien debe su existencia, su conservación y la innumerable abundancia de sus bienes. Por esta razón... los Estados no pueden obrar, sin incurrir en culpa, como si Dios no existiese, ni rechazar la religión como cosa extraña o inútil, ni pueden, por último, elegir indiferentemente una religión entre tantas. El Estado tiene la estricta obligación de admitir el culto divino en la forma con que el mismo Dios ha querido que se le venere. Es, por tanto, obligación grave de las autoridades honrar el santo nombre de Dios. Entre sus principales obligaciones deben colocar el 


\section{Concordato.}

El concordato se iniciaba "en el nombre de la Santísima e Individua Trinidad" y en su artículo 1 afirmaba que: "la religión católica, apostólica, romana es la de Colombia", reconociéndola los poderes públicos "como elemento esencial del orden social", razón por la cual "se obligan a protegerla y hacerla respetar, lo mismo que a sus ministros, conservándola a la vez en el pleno goce de sus derechos y prerrogativas". De este solemne reconocimiento se seguían una serie de consecuencias que enumeraban los artículos siguientes, a saber: la Iglesia católica conservaba su plena libertad e independencia de la potestad civil y, por consiguiente, sin ninguna intervención de ésta, podía ejercer libremente toda su autoridad espiritual y su jurisdicción eclesiástica, conformándose en su gobierno y administración con sus propias leyes (artículo 2), legislación canónica que es independiente de la civil y que, por lo mismo no formaba parte de ésta, pero que "será solemnemente respetada por las autoridades de la república" (artículo 3). Es el único concordato latinoamericano en que se hacía un reconocimiento tan explícito y se afirmaba un respeto tan irrestricto del derecho canónico.

Igualmente se hacía un expreso reconocimiento de la "personería jurídica de la Iglesia" representada por su legítima autoridad jerárquica, y de su "capacidad de gozar y ejercer los derechos que le corresponden" (artículo 4), razón por la cual la Iglesia tenía facultad de adquirir por justos títulos, de poseer y administrar libremente bienes muebles e inmuebles "en la forma establecida por el derecho común", siendo sus propiedades y fundaciones no menos inviolables que las de los ciudadanos de la república (artículo 5). Este trato común con los demás ciudadanos se extendía también a los tributos, pues dichas propiedades podían ser gravadas de la misma manera que las demás propiedades particulares, exceptuándose los edificios destinados al culto, los seminarios conciliares y las casas episcopales y curales, "que no podrán nunca gravarse con contribuciones, ni ocuparse a destinarse a usos diversos" (artículo 6). Por su parte, los ordinarios diocesanos y los párrocos podían cobrar de los fieles los emolumentos y proventos eclesiásticos canónica y equitativamente establecidos y que se fundasen, ya en la costumbre inmemorial de cada diócesis, ya en la prestación de servicios religiosos; y para que los actos y compromisos de este origen produjesen efectos civiles y la autoridad temporal les prestase su apoyo, los ordinarios procederían de acuerdo con el gobierno (artículo 9). En materia de cementerios, todo lo concerniente a ellos debía ser arreglado por el gobierno con los respectivos diocesanos, procurando conciliar las legítimas exigencias de carácter civil y sanitario con la veneración debida al lugar sagrado y las prescripciones eclesiásticas, siendo materia de un acuerdo especial de la Santa Sede y el gobierno cuando hubiese discordancia (artículo 30\%).

Se afirmaba el derecho que correspondía a la Santa Sede para nombrar los arzobispados y obispados vacantes, sin embargo de lo cual el papa: "como prueba de particular deferencia y con el fin de conservar la armonía entre la Iglesia y el Estado, conviene en que a la provisión de las sillas arzobispales y episcopales preceda

favorecer la religión, defenderla con eficacia, ponerla bajo el amparo de las leyes, no legislar nada que sea contrario a la incolumidad de aquélla". 
el agrado del presidente de la República". Para ello, en cada sede vacante, podía el presidente recomendar directamente a la Santa Sede los eclesiásticos que en su concepto reunieren las dotes y cualidades necesarias para la dignidad episcopal; y la Santa Sede, por su parte, antes de proceder al nombramiento manifestaría siempre los nombres de los candidatos que quisiera promover, con el fin de saber si el presidente tenía motivos de carácter civil o político "para considerar a dichos candidatos como personas no gratas”. En todo este procedimiento debía procurarse que las vacantes de las diócesis quedasen provistas lo más pronto posible de manera que no se prolongaren por más de seis meses (artículo 15). Podía la Santa Sede erigir nuevas diócesis y variar las circunscripciones de las existentes cuando lo creyere útil y oportuno para el mayor provecho de las almas "consultando previamente al gobierno y acogiendo las indicaciones de éste que fueren justas y convenientes" (artículo 16).

En lo que se refería a las personas naturales, los miembros del clero secular y regular no podrán ser obligados a desempeñar cargos públicos incompatibles con su ministerio y profesión, además de estar exentos del servicio militar (artículo 7). Por su parte, podían constituirse y establecerse libremente en el país órdenes y asociaciones religiosas de ambos sexos, toda vez que autorizase su canónica fundación la competente superioridad eclesiástica, las que se regirían por las constituciones propias del instituto; para gozar de personería jurídica y quedar bajo la protección de las leyes, eclesiástica (artículo 10). De preferencia, la Santa Sede prestaría su apoyo y cooperación al gobierno para que se establecieran en Colombia institutos religiosos dedicados principalmente al ejercicio de la caridad, a las misiones, a la educación de la juventud, a la enseñanza en general y a otras obras de utilidad pública y beneficencia (artículo 11). Y los convenios que se celebrasen entre la Santa Sede y el gobierno para el fomento de las misiones católicas "en las tribus bárbaras” no requerirían ulterior aprobación del congreso (artículo 31).

La educación e instrucción pública en las universidades, colegios, escuelas y demás centros de enseñanza sería organizada y dirigida "en conformidad con los dogmas y la moral de la religión católica", siendo obligatoria la enseñanza religiosa en tales centros, observándose en ellos "las prácticas piadosas de la religión católica" (artículo 12). Para que ello fuera efectivo, los respectivos ordinarios diocesanos, personalmente o por delegados, ejercerían el derecho de inspección y revisión de los textos en lo que se refería a la religión y la moral. En lo que se refería a la universidad, correspondía al arzobispo de Bogotá designar los libros que servirían de textos para la religión y la moral; y para la uniformidad en la enseñanza en estas materias, el arzobispo conjuntamente con los demás prelados elegirían los textos en los demás planteles de enseñanza oficial. Por su parte, el gobierno impediría que en el desempeño de asignaturas literarias y científicas y, en general, en todos los ramos de instrucción "se propaguen ideas contrarias al dogma católico y al respeto y veneración debidos a la Iglesia" (artículo 13). Y cuando la enseñanza de la religión y la moral, "a pesar de las órdenes y prevenciones del gobierno", no sea conforme a la doctrina católica, el respectivo ordinario diocesano podrá retirar a los profesores o maestros la facultad de enseñar en tales materias (artículo 14).

El matrimonio que debían celebrar los católicos produciría efectos civiles 
respecto a personas y bienes de los cónyuges y sus descendientes sólo cuando se celebraba de conformidad con las disposiciones del Concilio de Trento. Para que ello ocurriera, el acto de la celebración debía ser presenciado por el funcionario determinado por la ley con el solo objeto de verificar la inscripción del matrimonio en el registro civil, solemnidad de la que se podía prescindir tratándose de matrimonios in articulo mortis cuando no fuere fácil practicarla, reemplazándola por pruebas supletorias. Era de cargo de los contrayentes practicar las diligencias relativas a la intervención de funcionario civil para el registro, limitándose la acción del párroco a hacerles presente oportunamente la obligación que les imponía la ley civil (artículo 17). Para los efectos de probar los matrimonios tridentinos celebrados en cualquier tiempo y que debían surtir efectos civiles, se admitirían preferentemente las pruebas de origen eclesiástico (artículo 18). Los efectos civiles del matrimonio se regirían por el poder civil; pero serían de la exclusiva competencia de la autoridad eclesiástica las causas matrimoniales que afectasen al vínculo matrimonial y a la cohabitación de los cónyuges, así como las referidas a la validez de los esponsales (artículo 19).

Se asumía en el concordato el delicado tema de los bienes que habían sido usurpados a la Iglesia en los años anteriores, asumiendo el gobierno los pagos respectivos (artículos 22, 23 y 25), al tiempo que la Santa Sede, "en vista del estado en que se halla el tesoro nacional de Colombia y de la utilidad que deriva la Iglesia de la observancia de este convenio", hacía las necesarias condonaciones (artículos 24 y 29). Por su parte, los miembros sobrevivientes de las extinguidas comunidades religiosas continuarían disfrutando de la renta asignada por anteriores disposiciones para su manutención y demás necesidades (artículo 26); y lo mismo sucedería con las rentas anteriormente destinadas al sostenimiento del culto en capillas y otros lugares religiosos, debiendo entenderse el gobierno con la competente autoridad religiosa en caso de haber dudas o dificultades (artículo 27). El gobierno devolvería a las entidades religiosas los bienes desamortizados que les pertenecieren y que no tuviesen ningún destino; y para el evento de que el dueño no apareciere o no tuviere misión que cumplir, se aplicaría el producto de su venta o de su manejo a objetos análogos benéficos y piadosos, según las necesidades más apremiantes de cada diócesis, procediendo de acuerdo con la competente autoridad eclesiástica (artículo 28).

Las otras materias contempladas se referían a la obligación que asumía el gobierno de adoptar en las leyes de procedimiento criminal disposiciones que salvasen la dignidad sacerdotal siempre que por cualquier motivo tuviere que figurar en el proceso un ministro de la Iglesia (artículo 8). Los ejércitos de la república gozarían de las exenciones conocidas con el nombre de "privilegios castrenses" que serían determinados por el papa en acto separado (artículo 20). Después de los oficios divinos se haría en todas las iglesias de la república la siguiente oración: "Domine salvam fac rempublicam; Domine salvum fac praesidem eius et supremas eius auctoritates" (artículo 21). Los últimos dos artículos estaban dedicados a la derogación y abrogación de las leyes, órdenes y decretos que se opusieren al concordato, cualquiera fuese el modo o tiempo en que se hubiesen promulgado, concordato que tendría la fuerza de ley del Estado (artículo 32); y a 
la ratificación y canje del mismo, que se haría en los seis meses siguientes o antes si fuere posible (artículo 33).

\section{Convenciones complementarias.}

En los años siguientes el concordato de 1887 fue complementado por dos convenciones, ambas en el pontificado del mismo León XIII: la primera celebrada al año siguiente, el 24 de septiembre de 1888, cuya finalidad era promover la actuación de la parte final del artículo 25 del concordato, estableciendo el modo en que debía repartirse las suma anual de cien mil pesos que el gobierno debía a la Iglesia a título de indemnización ${ }^{56}$. La segunda, celebrada el 20 de julio de 1892, a fin de prevenir todo desacuerdo respecto del fuero clerical y principalmente en la aplicación del artículo 8 del concordato, así como para dar cumplida ejecución al artículo 30 sobre cementerios y establecer lo más conveniente sobre el registro civil $^{57}$. Lo destacable en materia de fuero era que, salvas las causas meramente espirituales de los eclesiásticos, todas las civiles y criminales quedaban entregadas a la justicia estatal, pero los juicios criminales no serían públicos, serían conocidos por los jueces superiores de distrito judicial sin intervención del jurado y, en segunda, por los tribunales; las causas criminales contra dignidades eclesiásticas serían de conocimiento de los tribunales superiores de primera instancia y por la Corte Suprema en segunda, en tanto que las causas mayores de obispos serían conocidas por la Santa Sede.

La llegada de los conservadores al poder en 1885 no eliminó los conflictos, pero los conservadores se mantuvieron en el poder hasta 1930, lo que permitió los acuerdos complementarios mencionados. Hacia mediados del siglo XX, se adoptó un nuevo acuerdo en 1942, pero como no fue ratificado, el concordato de 1887 continuó en vigor hasta que fue sustituido, después del Concilio Vaticano II, en $1973^{58}$.

\section{Dos EXCURSOS}

\section{La concesión del derecho de patronato al presidente de la República del Perú.}

Los concordatos que he descrito precedentemente son los que se celebraron entre la Santa Sede y los países latinoamericanos durante el siglo XIX. No hubo otros. Pero, además de ellos, sin tener, empero, carácter concordatario, hubo un acto de la Sede Apostólica que no se puede omitir: es la bula "Preclara inter beneficia” por la que, el 5 de marzo de $1874^{59}$, el papa Pío IX concedió el derecho de patronato al presidente de la República del Perú y a sus sucesores, durante el

${ }^{56} \mathrm{Su}$ texto en Enchiridion, cit. (n. 4), pp. 514-521, N 986-999.

${ }^{57} \mathrm{Su}$ texto en Enchiridion, cit. (n. 4), pp. 544-556, N 1037-1064; también en MerCATI, Angelo, cit. (n. 14), I, pp. 1061-1069.

${ }^{58} \mathrm{Su}$ texto en Enchiridion, cit. (n. 4), pp. 1420-1441, №3067-3115; también en SANTOS Díaz, José Luis; Corral Salvador, Carlos, cit. (n. 24), pp. 289-297.

${ }^{59} \mathrm{Su}$ texto en Enchiridion, cit. (n. 4), pp. 426-431, N 800-804. En castellano en RUDA SANTOlaria, Juan José, Los sujetos de derecho internacional. El caso de la Iglesia católica y del Estado de la Ciudad del Vaticano (Lima, 1995), pp. 586-589. 
período de su cargo, que profesaran la fe católica. El contenido de la concesión era que dichos presidentes pudieren fruir del derecho de patronato del que, antes de la independencia del gobierno español, gozaban los reyes de España por concesión de la Santa Sede. Esta concesión se hacía con una "condición solemne": que cuanto fue asignado como dotación tanto al clero como al ejercicio del sagrado ministerio de culto en las diócesis del territorio de la república fuese conservado íntegra y diligentemente, y fuese fielmente asignado, conjuntamente con la perseverancia del gobierno peruano en promover y garantizar la religión católica.

De ser respetadas las condiciones anteriores, el presidente de la república y sus sucesores tendrían el derecho de presentar a la Sede Apostólica para las sedes arzobispales y episcopales vacantes hombres eclesiásticos dignos e idóneos, a los cuales se daría, según las reglas prescritas por la Iglesia, la institución canónica, presentación que debía hacerse dentro del año de la vacancia si no hubiese legítimo impedimento. También el presidente de la república tendría el derecho de presentar al obispo, hombres canónicamente dignos para cada capítulo. En fin, en los templos del Perú, el presidente de la república gozaría de los mismos honores que en un tiempo fueron tributados al rey de España por el derecho de patronato concedido por la Santa Sede.

Las razones que movieron a la Santa Sede para una tal concesión, tal como se consigna en la bula, se resumían en el celo del pueblo peruano, por una parte, en acoger y asumir la fe católica predicada desde el principio del período hispano, al punto que algunos habían llegado al heroísmo en la fe por lo que habían sido elevados a los altares, y quedaba reflejada en la Constitución de 1860, que declaraba solemnemente que: "el Perú profesa la religión católica y la garantiza, y no tolera el ejercicio público de otra religión” (artículo 4); y, por otra, las muchas iniciativas del gobierno a favor de la religión.

La concesión del patronato se hizo durante el gobierno de Manuel Pardo (1872-1876), primer presidente civil en la historia de Perú independiente, pero ni durante su mandato ni del de su sucesor, Mariano Ignacio Prado (1876-1879) se otorgó el exequátur a las letras apostólicas, por la influencia de los liberales en el congreso, sino que lo hizo, seis años después, el 27 de enero de 1880, el gobierno dictatorial de Nicolás de Piérola (1879-1881), decretando que sería considerado como ley del Estado y regiría perpetuamente ${ }^{60}$. En 1886, el congreso peruano anuló los actos del gobierno de Piérola, pero quedaron subsistentes los acuerdos internacionales en virtud del principio de derecho internacional "pacta sund servanda”. La bula siguió vigente durante las Constituciones de 1920 y 1933, hasta la firma del Acuerdo entre la Santa Sede y el gobierno peruano de $1980^{61}$.

${ }^{60}$ Exequátur de Nicolás de Piérola, Jefe supremo de la República, a las Letras Apostólicas de Pío IX. Lima, 27 de enero de 1880, en Ruda SANTOlaria, Juan José, Los sujetos, cit. (n. 59), p. 590.

${ }^{61}$ Krebs, Ricardo, cit. (n. 30), pp. 238-241; Revilla Izquierdo, Milagros Aurora, Sistema de relaciones Iglesia-Estado peruano: los principios rectores del derecho eclesiástico del Estado en el ordenamiento jurídico peruano (Lima, tesis de magister, 2013); RUDA SANTOLARIA, Juan José, Las relaciones entre la Iglesia y el Estado a la luz de las Constituciones peruanas del siglo XIX, en Revista de Estudios Histórico-Jurídicos 24 (2002), pp. 57-77; Vargas UGarTe, Rubén, Historia de la Iglesia en el Perú, V: 1800-1900 (Burgos, 1962). 


\section{Los intentos de concordato entre Chile y la Santa Sede durante el siglo XIX.}

Las relaciones entre Chile y la Santa Sede se iniciaron pronto después de la independencia y, con diversas vicisitudes, abordaron los principales temas de interés común ${ }^{62}$. La misión de mayor envergadura enviada por Chile durante el siglo XIX fue la Misión encabezada por Ramón Luis Irarrázabal entre 1847 y 1850. En calidad de enviado extraordinario y ministro plenipotenciario, presentó sus credenciales al nuevo pontífice Pío IX, el 22 de junio de $1847^{63}$. Las materias que debía abordar la misión eran amplias y alguna, como la preconización del nuevo arzobispo de Santiago, don Rafael Valentín Valdivieso, fue de fácil despacho; alguna otra, como la designación de Justo Donoso como obispo de Ancud, fue más laboriosa. El resto, por sugerencia de la misma Santa Sede, serían abordadas en un proyecto de concordato, entre las cuales se consideraban la concesión del patronato, el indulto de la bula de cruzada, una nueva organización de las sociedades religiosas de seglares, un tribunal eclesiástico de tercera instancia en Santiago, la reforma de las órdenes de regulares, diversas facultades para los obispos diocesanos, una jurisdicción castrense y un ambicioso plan de misiones para el sur del país, desde Arauco a Magallanes. Poco se pudo avanzar en el concordato, el que, a pesar de las dificultades por la que pasaba la Santa Sede -las que obligaron a Pío IX huir a Gaeta, donde viajó Irarrázabal- fue estudiado por una comisión de cardenales a petición del mismo Pontífice. Pero, aunque los cardenales estimaron que se podía conceder al presidente de la república el derecho de nominación de obispos y canónigos, entendían que no podían acceder al patronato en los términos propuestos por el representante chileno. Llegada a su fin la misión por decisión del Congreso chileno, la Santa Sede accedió a varias de las materias propuestas, como el tribunal de tercera instancia para Chile, la reforma de las órdenes religiosas, la jurisdicción eclesiástica castrense, la bula de cruzada, el traslado del ayuno en las témporas de septiembre y las organizaciones de seglares, pero la Constitución chilena de 1833 fue el obstáculo principal y, por lo mismo, no se pudo llegar a un acuerdo general. Resulta interesante, sin embargo, advertir que detrás de esta misión y, en general, de aquellas que perseguían obtener de la Santa Sede el reconocimiento del patronato, se puede advertir la falta de convencimiento de las autoridades chilenas de que la mera invocación de ser herederos de los derechos de la antigua monarquía española fuese título suficiente para justificarlo; de allí su interés de obtener un reconocimiento directo por la autoridad pontificia. Todos sus esfuerzos, empero, fueron en vano.

Nuevos intentos hizo Blanco Encalada, a la sazón ministro en Paris. Pro-

${ }^{62}$ GonZÁlez ECheniQue, Javier, Esquema de las relaciones entre la Iglesia y el Estado 1541 1925, en Diplomacia, 39 (1987), pp. 31-40; Oviedo CAVADA, Carlos, Un siglo de relaciones entre la Santa Sede y Chile, 1822-1925, en Diplomacia, 39 (1987), pp. 18-30; El MISMO, Negociaciones chilenas sobre convenios con la Santa Sede, en Finis Terrae, 19 (1958), pp. 37-53; El MISMo,La misión Irarrázabal en Roma 1847-1850 (Santiago, 1962); SALINAS ARANEDA, Carlos, Relaciones Iglesia-Estado, en SÁNCHez GAETE, Marcial (director), Historia de la Iglesia en Chile, III: Los nuevos caminos: la Iglesia y el Estado (Santiago, 2011), pp. 251-256.

${ }^{63}$ Retamal Fuentes, Fernando, Chilensia Pontificia. Monumenta Ecclesiae Chilensia (Santiago, 1998), I, 1, p. 323. Oviedo CavadA, Carlos, La Misión Irarrázabal, cit. (n. 63). 
yectando pasar la Semana Santa de 1855 en Roma, se ofreció al gobierno para abordar algún asunto en que éste tuviera interés. El gobierno le encomendó, entre otros, continuar con las conversaciones para concluir el concordato, pero éste no avanzó, aun cuando el encargado de la Santa Sede para este asunto, Giuseppe Barnabó, viajó a París a continuar las conversaciones con Blanco Encalada, siendo la Constitución de 1833 el gran escollo.

Las dificultades por las que pasaron después las relaciones entre Chile y la Santa Sede, que llegaron a la ruptura de relaciones, no permitieron seguir insistiendo en un posible concordato el cual fue finalmente excluido por parte del presidente José Manuel Balmaceda (1886-1891), a pesar del empeño que puso en superar las tensiones.

\section{Consideraciones finales}

Producida la independencia de los países latinoamericanos y fenecida la restauración en 1848, la Santa Sede firmó concordatos con diversas naciones hispanoamericanas, tanto durante el pontificado de Pío IX como de León XIII, textos internacionales que también se firmaron con países europeos, si bien los más numerosos fueron los primeros. En el largo pontificado de Pío IX la celebración de dichos documentos se sitúa en los diez primeros años de su pontificado.

El primero de dichos concordatos fue el celebrado con Bolivia de 1851 en que, si bien nunca entró en vigencia, fue el modelo que se siguió en los concordatos siguientes, tanto en las materias incluidas en ellos como en el orden en que las mismas son expuestas. La cercanía del modelo se manifiesta, incluso, en la copia textual de algunos artículos, sin perjuicio de que en ellos queden igualmente reflejadas las peculiaridades de los distintos Estados firmantes. Excepción a esto es el concordato celebrado con Haití que, a diferencia de los demás, sigue de cerca al concordato celebrado a principios de siglo entre Napoleón Bonaparte y el papa Pío VII (1800-1823).

La celebración de estos concordatos estuvo estrechamente vinculada a la difícil situación política por la que atravesaron los países firmantes. Por lo general, detrás de ellos estaban los grupos políticos conservadores. Pero estas mismas vicisitudes políticas determinaron la suerte de la mayoría de ellos cuando accedían al poder los grupos liberales, haciendo que la vigencia de la mayoría de ellos fuera corta en el tiempo, no faltando el caso de que ni siquiera alcanzara a entrar en vigencia, como el primer de todos ellos, el concordato con Bolivia de 1851. No obstante lo anterior, hubo alguno cuya vigencia se prolongó en el tiempo pasando al siglo siguiente, como el de Colombia de 1887.

El patronato es una de las cláusulas que se encuentra en todos estos textos. Era la manera con que los Estados americanos lograban legitimar la situación de hecho que se había producido al continuar unilateralmente, producida que fue la independencia, con el patronato que la Santa Sede había concedido en el siglo XVI a los reyes de España. Incluso se llegó a conceder el patronato sin un concordato, como ocurrió con Perú, el que permanecería vigente hasta muy entrado el siglo XX. 
El contenido similar que presentan los concordatos de Pío IX se rompe con el concordato firmado por el mismo pontífice con Ecuador, el año 1862, el último de los concordatos latinoamericanos celebrados por este papa, que fue, a la vez, el concordato más favorable a la Iglesia de todos los concordatos latinoamericanos decimonónicos. El nuevo pontífice, León XIII, daría una nueva orientación a las relaciones entre la Iglesia y los Estados, cuyos principios quedaron fijados en la encíclica Immortale Dei, de 1885, lo que queda reflejado en el concordato celebrado con Colombia, el último del siglo, cuyo contenido difiere de los primeros concordatos del siglo.

Los primeros concordatos fueron celebrados todos ellos cuando aún existían los Estados Pontificios. Cuando la unificación italiana puso fin a los mismos, ello no significó que se detuviera la actividad concordataria de la Santa Sede como lo prueban los concordatos celebrados por León XIII con los países, no sólo del continente latinoamericano, sino también europeos.

Chile no fue ajeno al deseo de firmar un concordato con la Santa Sede, para lo cual envió a Roma misiones diplomáticas con ese fin. Los intentos en tal sentido, sin embargo, no fueron coronados con el éxito, a pesar del interés manifestado también por la Santa Sede. El gran obstáculo lo presentó la Constitución de 1833 que proporcionaba el marco legal dentro del cual debían actuar las autoridades chilenas, pero cuyo acentuado patronatismo no era aceptado por la Iglesia.

BibLIOGRAFÍA

Arellano, Jorge Eduardo, Breve historia de la Iglesia en Nicaragua (1523-1979) (Managua, 1981).

Arjona Colomo, Miguel, Historia de América, II: América del Sur (Madrid, Epesa, 1976).

Catecismo de la Iglesia Católica (1992).

Corral Salvador, Carlos - Giménez Martínez Carvajal, José, Concordatos vigentes (Madrid, Fundación Universitaria Española, 1981), 2 vols.

De Echeverría, Lamberto, Haití, en Corral Salvador, Carlos - Giménez Martínez Carvajal, José, Concordatos vigentes (Madrid, Fundación Universitaria Española, 1981), II.

Donoso, Justo, Instituciones de Derecho canónico americano (Valparaíso, Imprenta y librería del Mercurio, 1848-1849), 2 vols.

Enchiridion dei concordati. Due secoli di Storia dei rapporti Chiesa-Stato (Bologna, Dehoniane, 2003).

Estrada Monroy, Agustín, Noticia cronológica de las leyes emitidas en Guatemala tocantes a la religión y a la Iglesia católica, en Estudios Teológicos, 7 (Guatemala, 1980), 14.

GONZÁlEZ ECHENIQUE, Javier, Esquema de las relaciones entre la Iglesia y el Estado 15411925, en Diplomacia, 39 (1987).

Krebs, Ricardo, La Iglesia de América Latina en el siglo XIX (Santiago, Ediciones Universidad Católica de Chile, 2002).

LEÓN XIII, Encíclica Immortale Dei (1885).

Los sacrosantos ecuménicos concilios de Trento y Vaticano (Madrid, 1903). 
Mercati, Angelo (editor), Raccolta di concordati su materie ecclesiastiche tra la Santa Sede e le autorità civili, I: 1098-1914 (Tipografia Poligotta Vaticana, 1954).

Melgar Guzmán, Rafael Antonio, La Iglesia católica y el Estado en Guatemala, de la independencia a la revolución liberal (1821-1871), en Estudios Teológicos, 8 (Guatemala, 1981) 16.

MilLer, Hubert J., La Iglesia y el Estado en tiempo de Justo Rufino Barrios (Guatemala, Universidad de San Carlos de Guatemala, 1976).

MinneraTH, Roland, L'Église et les États concordataires (1846-1981). La souveraineté spirituelle (Paris, Les Éditios du Cerf, 1983).

Minnerath, Roland, L'Église catholique face aux États. Deux siècles de pratique concordataire 1801-2010 (Paris, Les Éditions du Cerf, 2012).

Oviedo Cavada, Carlos, Un siglo de relaciones entre la Santa Sede y Chile, 1822-1925, en Diplomacia, 39 (1987).

Oviedo Cavada, Carlos, Negociaciones chilenas sobre convenios con la Santa Sede, en Finis Terrae, 19 (1958).

Oviedo Cavada, Carlos, La misión Irarrázabal en Roma 1847-1850 (Santiago, 1962).

Petschen, Santiago, Venezuela, en Corral Salvador, Carlos - Giménez Martínez CARvajal, José, Concordatos vigentes (Madrid, Fundación Universitaria Española, 1981), II.

Pío IX, constitución Romanus Pontifex, de 28 de agosto de 1873.

Retamal Fuentes, Fernando, Chilensia Pontificia. Monumenta Ecclesiae Chilensia (Santiago, 1998), I,1.

Revilla IzQuierdo, Milagros Aurora, Sistema de relaciones Iglesia-Estado peruano: los principios rectores del derecho eclesiástico del Estado en el ordenamiento jurídico peruano (Lima, tesis de magister, 2013).

ROBERT, Paul, L'Église et la première république noire (Rennes, s.d. [pero 1967]).

Ruda SAntolaria, Juan José, Los sujetos de derecho internacional. El caso de la Iglesia católica y del Estado de la Ciudad del Vaticano (Lima, 1995).

Ruda Santolaria, Juan José, Las relaciones entre la Iglesia y el Estado a la luz de las Constituciones peruanas del siglo XIX, en Revista de Estudios Histórico-Jurídicos, 24 (2002).

Salinas Araneda, Carlos, Relaciones Iglesia-Estado, en Sánchez Gaete, Marcial (director), Historia de la Iglesia en Chile, III: Los nuevos caminos: la Iglesia y el Estado (Santiago, 2011).

SÁnCHEZ, Luis Alberto, Historia General de América (4a edición, Santiago, Ediciones Ercilla, 1945), II.

Santos Díez, José Luis - Corral Salvador, Carlos, Acuerdos entre la Santa Sede y los Estados. Versión española de los textos (Madrid, BAC, 2006).

Vargas Ugarte, Rubén, Historia de la Iglesia en el Perú, V: 1800-1900 (Burgos, 1962). 